\title{
The 2014 Bowman Lecture-Bowman's and Bruch's: a tale of two membranes during the laser revolution
}

\begin{abstract}
To describe the historical evolution of the role of lasers in effecting therapeutic changes in the four acellular membranes of the eye. Over the past 50 years, iterative developments have been instituted in lasers used for various forms of eye surgery predominately on the basis of data generated in early experiments in the 1960s to determine thresholds for damage and their incorporation in codes of practice for laser safety. The evolutionary steps are described. Excimer laser technology resulted in the generation of the new field of laser refractive surgery with over 40 million individuals now having undergone procedures such as photorefractive keratectomy and LASIK. Developments in lasers used for various forms of retinal surgery have undergone changes involving shorter and shorter pulse durations together with changes in beam energy distribution with implications for potential intervention in AMD prophylactically. Lasers have made a major impact on surgical treatment on all four acellular membranes of the eye but particularly Bowman's membrane in refractive surgery, where it has been demonstrated that it can be removed without significant consequences for eye health or vision. Eye (2015) 29, 46-64; doi:10.1038/eye.2014.240
\end{abstract}

In February 1840, William Bowman qualified as a doctor, and 1 year later, at the remarkably young age of 25 years, he was elected a Fellow of the Royal Society for his seminal work on striated muscle; however, he had to wait a further 6 years (1846) to be appointed assistant surgeon at the Royal London Ophthalmic Hospital (Moorfields Eye Hospital) becoming a surgeon at the institution in 1851. His contributions to medicine were rewarded with a Baronetcy in 1884. It should be remembered, however, that he was an extremely modest and humble man who throughout his life never used the eponymous labels associated with his many discoveries preferring Malpighi capsule for glomerular capsule (Bowman's capsule); radial fibres of the ciliary muscle (Bowman's muscle); the glands in the olfactory mucosa (Bowman's glands); and anterior elastic membrane for Bowman's membrane. In 1883, the Council of the Ophthalmic Society of the United Kingdom honoured its founder Sir William Bowman by inaugurating the Bowman lectures in recognition of his distinguished scientific position in Ophthalmology and other branches of medicine and in commemoration of his valuable services to the Ophthalmological Society, of which he was the first President. The Bowman lecturers were charged with delivering a lecture, which should consist of a critical review of recent advances in a given field of Ophthalmology. My predecessors have expounded in detail on the many and varied contributions made to our understanding of tissues by William Bowman and also his role in developing Ophthalmology in the United Kingdom. ${ }^{1,2}$ I was therefore particularly honoured and somewhat intimidated on being asked to deliver the 65th lecture in this series as I am not an ophthalmologist. Like almost all of the previous lecturers, I decided to look backwards before going forwards. Bowman interacted with the elite of Victorian society; he was a contemporary of Dickens, corresponded with Darwin over organisational matters concerning the 1851 great exhibition, and with
Received: 20 August 2014 Accepted in revised form: 27 August 2014 
Florence Nightingale over the passage of nurses to Scutari in the Crimea. It should be remembered, however, that the vast majority of people within the United Kingdom lived a very different life in a very different environment. The plight of the poor is amply described by Dickens in his many novels, ${ }^{3}$ and the seminal works of Mayhew such as 'London Labour and London Poor'. 4 These moving descriptions are supported by the graphical if depressing and threatening illustrations of Gustaf Dore in his work 'London: A pilgrimage' ${ }^{5}$ I claim a tenuous link with history in that Bowman helped Florence Nightingale at a time when her endeavours to alleviate the suffering of British soldiers were not looked upon with favour by the British Government. ${ }^{6}$ At the age of 4 years, Sir Harold Ridley sat upon the lap of Florence Nightingale and presumably she was kind to him. Sir Harold was certainly kind to me when I was feeling particularly bruised by peers who thought that changing the properties of the optical zone of the cornea was as dangerous, and possibly even more unpopular, than his own concept of introducing a plastic lens into the eye subsequent to cataract surgery. At a bar in Torquay he asked me why I was looking so depressed and when I told him it was because of peer criticism, he said 'I have been through that my boy and the only way to deal with such ill informed critics is to live longer than them'. I am forever grateful to him for his advice and for providing this somewhat tenuous link to Bowman. As the 65th Bowman lecturer, I would first like to draw attention to all my predecessors (Figure 1). This is an incredible group of people, including 2 peers of the realm, 8 knights, and 28 professors, a truly humbling alumni and certainly one representing the greats of ophthalmology. In the face of this array, I felt a little like Sydney Carton on proceeding to the guillotine in 'A Tale of Two Cities' and to amend his famous statement, 'It is a far, far better thing that I HOPE I do, than I have ever done' ${ }^{7}$ Hence, the title of my lecture.

My chosen subject brings together my interest in two remote structures in the eye together with a technology, which has had a major impact throughout the globe, lasers. It would also appear to be the first Bowman's lecture to spend a significant amount of time describing research on Bowman's membrane, although I have to confess my contribution has been essentially to destroy it.

In the past, the acellular membranes of the eye, the socalled 'glass membranes', ${ }^{8}$ have received scant attention from clinicians but have promulgated lengthy and heated discussion by anatomists and histopathologists. Moving from the front of the eye to the back, these four membrane systems are Bowman's membrane, Descemet's membrane, the capsule of the lens, and Bruch's membrane (Figure 2). Bowman's and Bruch's could be considered as the tendons of the eye as they provide incredibly strong structures deformable only within certain elastic limits and effectively run around the circumference of the globe. Together these two systems provide a biomechanical infrastructure to allow for the containment of intraocular pressure, pressure fluctuations due to cardiac cycle, the dissipation of forces implicit in accommodation, and tensional changes induced by the contraction and relaxation of extraocular muscles.

In a review of the literature, it seems that Bowman remains unchallenged in describing his membrane in a paper published in 1847. ${ }^{9}$ By contrast, Descemet's membrane has several claimants for discovery and was first described in a paper by an Englishman, Benedict Duddell in $1729^{10}$ some 30 years before the publication of Jean Descemet in $1759 .{ }^{11}$ Although Duddell seems to have been ignored by Descemet, there was a great deal of controversy as to whose name should be apportioned to the membrane from another Frenchman, Pierre Demours, who published in $1767 .{ }^{12}$ Perhaps, we should take a typically unBritish stance and rename this membrane Duddell's membrane. The lens capsule remains unburdened by an eponymous label and various individuals seem to have discovered or alluded to it over many years. The first is in a manuscript by Rufus of Ephesus in $100 \mathrm{AD},{ }^{13}$ followed by Christoforus Scheiner in the 1500s, ${ }^{14}$ Anthony van Leeuwenhoek in the 1600s, and Johann Gottfried Zinn ${ }^{15}$ in the 1700 s. Bruch was also lucky in having no real contenders for previously describing his membrane as although the Polish anatomist Frederick Ruysch described a system called tunica Reischiana, ${ }^{16}$ this was a composite structure almost certainly involving pigment epithelium, what we now call Bruch's membrane ${ }^{17}$ and a significant portion of the choroidal vasculature.

All of these membranes have in common the presence of collagen, which provides their rigidity. In Bowman's membrane, the collagen fibrils are extremely small in diameter (24-27 nm) and highly interwoven before interacting with the basement membrane of the corneal epithelium anteriorly and the larger diameter collagen fibres $(32-36 \mathrm{~nm})$ within the lamellae of the stroma anteriorly. ${ }^{18}$ By contrast, there are two layers of collagen within Bruch's membrane, which are separated by a layer of elastin (Figure 3). ${ }^{19}$ The inner collagenous layer is adjacent to the basement membrane of the retinal pigment epithelium, whereas the outer collagenous layer is associated with the basement membrane of the endothelial cells of the choriocapillaris and runs into the intercapillary columns. With age most acellular membranes increase in thickness and this is certainly the case for all such membranes within the eye, ${ }^{18,19}$ with the 


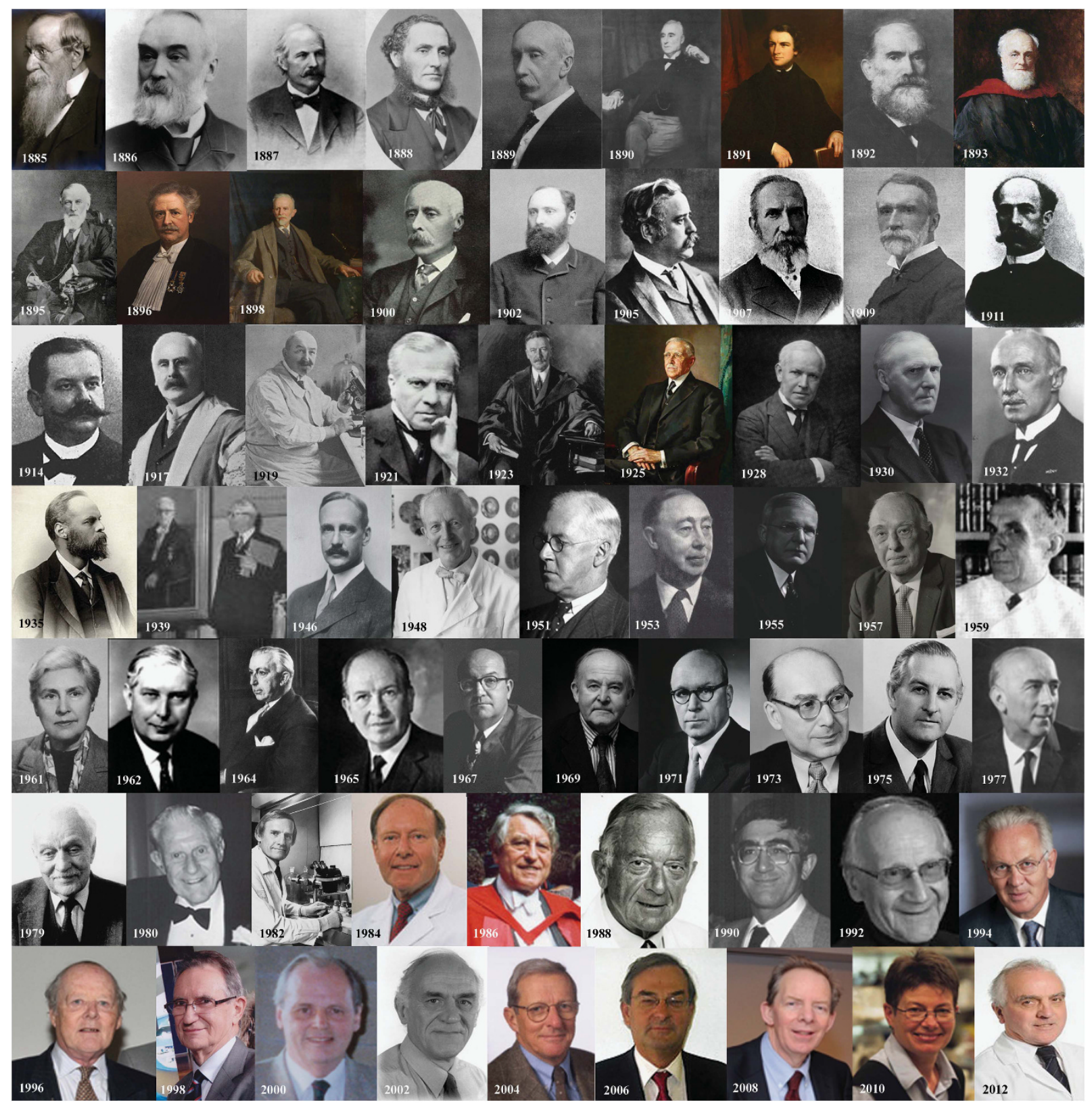

Figure 1 Illustrations of all 64 Bowman lecturers between 1885 and 2012 are shown as follows: 1885-Sir Jonathan Hutchinson, 1886-J Hughlings Jackson, 1887-Professor Wilhelm Von Zehender, 1888-Henry Power, 1889-Henry R Swanzy, 1890—Professor Edmund H Grut, 1891-John W Hulke, 1892—Professor Theodor Leber, 1893-T Pridgin Teale, 1895—WR Gowers, 1896-Professor H Snellen, 1898-Priestly Smith, 1900-R Marcus Gunn, 1902-Professor Ernst Fuchs, 1905—Sir FW Mott, 1907-Professor Theodor Sattler, 1909-Edward Nettleship, 1911—Professor Edmund Landolt, 1914—Professor W Uhthoff, 1917-Sir George Berry, 1919—V Morax, 1921-E Treacher Collins, 1923-GE de Schweinitz, 1925-Sir John Parsons, 1928—G Elliot Smith, 1930—Sir Arthur Keith, 1932-J Van der Hoeve, 1935-CH Usher, 1939-Professor H Weve, 1946-Arnold Knapp, 1948_Professor Marc Amsler, 1951-Sir Henry Dale, 1953-Sir Geoffrey Jeffeson, 1955-John H Dunnington, 1957—Sir Stewart Duke-Elder, 1959—Professor Louis Paufique, 1961-Professor Ida Mann, 1962-Lord Brain, 1964-Lord Cohen of Birkenhead, 1965-Professor Norman Ashton, 1967-Professor Michael J Hogan, 1969_Professor Sir George Pickering, 1971_Professor Algernon Reese, 1973_Professor Hans Goldmann, 1975Professor Barrie Jones, 1977-Professor D Whitteridge, 1979—Professor Hugh Davson, 1980—Lorenz E. Zimmermann, 1982—Richard W Young, 1984-Carl Kupfer, 1986-Wallace S Foulds, 1988-Gunter von Noorden, 1990-John L Pearce, 1992-Stephen M Drance, 1994-Professor GOH Naumann, 1996-Michael Sanders, 1999_Professor Desmond Archer, 2000—Professor David Easty, 2002Professor Alan Bird, 2004_Professor David Taylor, 2006_Professor Alistair Fielder, 2008_Professor Roger Hitchings, 2010—Professor Brenda Gallie, and 2012-Professor John Forrester. 


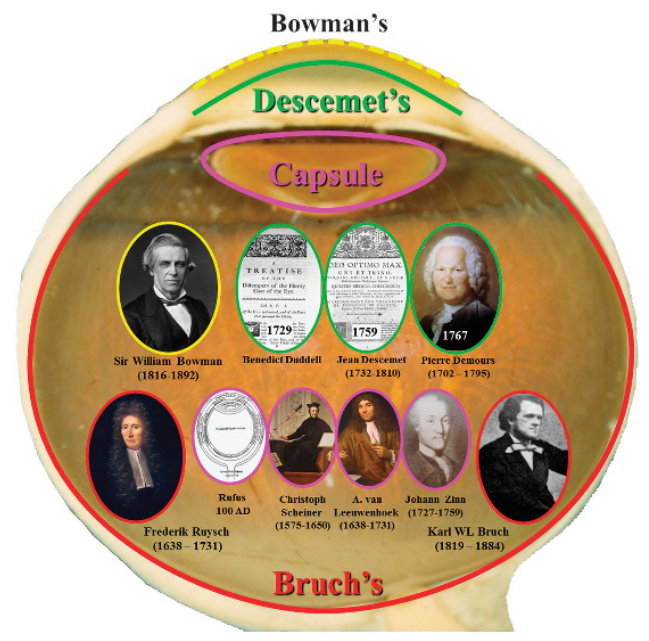

Figure 2 Illustration of the locations and discoverers of the acellular membranes of the eye.

possible exception of a recent report suggesting that Bowman's layer thins, ${ }^{20}$ although the resolution of the technique is questionable. The underlying causes of agerelated changes in Bruch's membrane and their implications for age-related retinal disease will be discussed later. Each of the four acellular membranes have become targets for surgical intervention using lasers.

The laser revolution was really initiated as a theoretical postulation by Albert Einstein in 1917, ${ }^{21}$ but he thought it a trivial component of his theory of relativity.

Interestingly, Einstein had a problem unbeknown to him initiated by the then chairman of the Nobel Prize committee an ophthalmologist, Alvar Gulstrand.

Gulstrand considered Einstein's work on relativity to be of questionable value and it was not until another Scandinavian and Nobel laureate, Neils Bohr took up Einstein's case and pressurised the committee to award a Nobel Prize to Einstein. Such however was the power of Gulstrand that Einstein's prize was not for relativity but for creating the photoelectric cell. The obvious moral of this story is do not upset important ophthalmologists.

Einstein's theoretical concept was first demonstrated practically in the microwave region of the electromagnetic spectrum with the creation of the Maser (microwave amplification by stimulated emission of radiation) by Charles Townes in $1955,{ }^{22}$ who received his Nobel Prize in 1964. The first laser was demonstrated in 1960 by Theodore Maiman, ${ }^{23}$ who also received his Nobel Prize in 1964 and the first eye exposure occurred in $1961 .{ }^{24}$

I was approached in 1965 with the possibility of pursuing a $\mathrm{PhD}$ on laser damage to the retina funded by the Royal Air Force and located jointly between the Institute of Ophthalmology in Judd Street and the

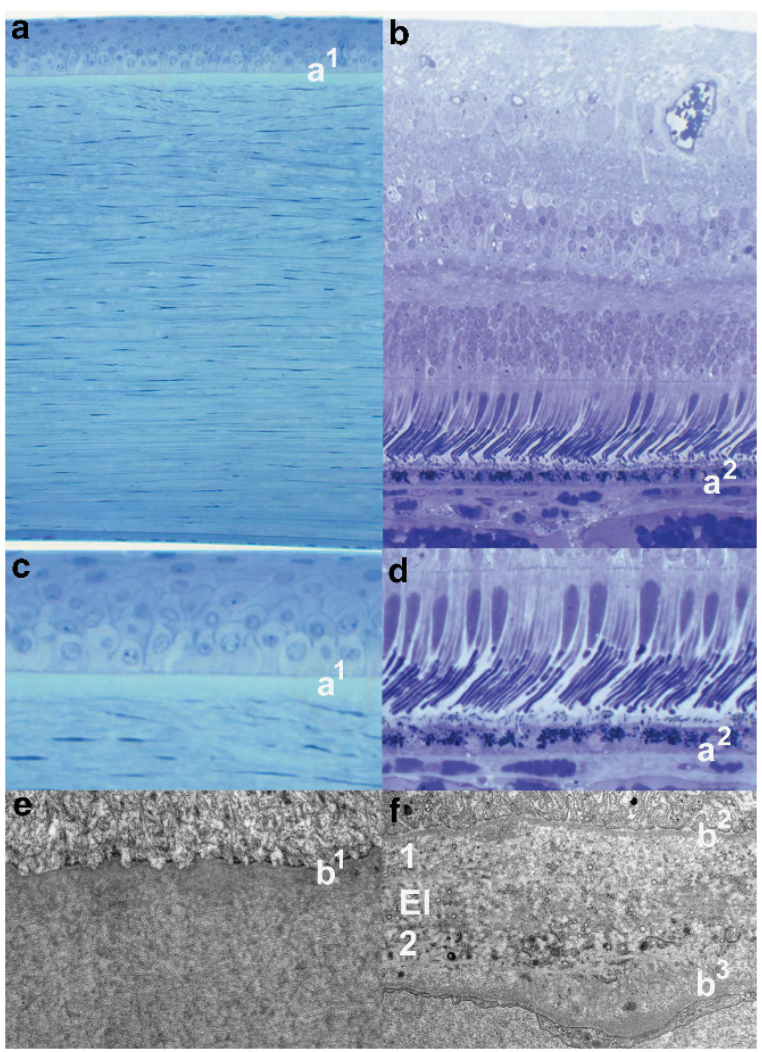

Figure 3 Light microscopy of the human cornea and retina. ( $a$ and $b$ ) The locations of Bowman's $\left(a^{1}\right)$ and Bruch's $\left(a^{2}\right)$ membranes seen in a higher power in (c and $d$ ), respectively. Transmission electron micrographs of Bowman's (e) and Bruch's (f) showing the basement membrane of the corneal epithelium $\left(b^{1}\right)$ overlying a fine matrix of collagen fibrils in (e), while the basement membranes of retinal pigment epithelium $\left(b^{2}\right)$ and the endothelial cells of the choriocapillaris $\left(b^{3}\right)$ are seen in (f). The inner and outer layers of Bruch's membrane are labelled 1 and 2, respectively, and are separated by the elastin layer $\mathrm{El}$ in (f).

Institute of Aviation Medicine in Farnborough, Hants. You can imagine the excitement of a newly graduated student who had just watched the film 'Goldfinger' being offered the possibility to work with a totally new technology funded by the then seemingly bottomless pit of Defence money. My brief was to determine safety limits, which would enable aircrew and other members of the Armed Forces to be protected from a weapon system that at the time did not exist but which could be imagined. I was lucky enough to have a wonderful tutor in Kit Pedler, a unique individual who had qualified in medicine and pathology before becoming an anatomist. In any Google search he will be found as an author and as the person who invented the Cybermen for Doctor Who. Having got the job Kit said to me 'if you need any help in the next three years come and see me'. Such were PhD's in the early 1960s and it was a great training with a really wonderful and creative scientist. 
After 3 years of intense research, the project ended with a very clear understanding of the ways in which laser beams interacted with biological tissue, interrelationships between wavelength, pulse duration, energy and spot size, and the mechanisms by which such exposures damaged ocular tissues in particular. ${ }^{25-30}$

These data are incorporated in various codes of practice throughout the world and resulted in me sitting on most of the committees of various institutions responsible for protecting individuals against various forms of nonionising radiation. ${ }^{31}$ At the same time, the understanding derived from such mechanisms allowed the framework for the development of various novel laser-based forms of therapy. One unsatisfactory development was that the figures generated by my research were also useful in the development of antipersonnel laser weapons. When I became aware of these developments, I worked diligently with the International Committee of the Red Cross to initiate a Geneva Convention banning the manufacture, distribution, and use of blinding laser weapons. ${ }^{32}$ I addressed the United Nations on the subject and we were very pleased that the Geneva Convention was created banning the manufacture, distribution and deployment of antipersonnel laser weapons.

Unfortunately, such is the importance of lasers and optical systems on the modern battlefield that individuals will still be at risk because such devices as target illuminators and rangefinders operate at energy levels, which will result in blinding injuries. ${ }^{32}$ However, as such devices are not specifically designed to blind, they are outside the scope of the convention.

In the 1970s and 1980s, much work was carried out improving lasers for treating retinal vascular diseases and together with the Moorfields group I was party to removing the $488 \mathrm{~nm}$ line of argon lasers, thereby removing the potential for collateral damage because of absorption of the blue radiation in the luteal pigment. ${ }^{33}$ Work also showed the limited importance of wavelength in trying to produce specific damage to the retina and to some extent reduced the need for the then novel Dye lasers. ${ }^{34}$ Studies at this time demonstrated that pulse duration was much more important in terms of limiting laser damage to a specific retinal layer, and this will be discussed later. ${ }^{35}$ Perhaps, one further important advent was the introduction of Diode lasers, which significantly reduced the cost and size of clinical devices. ${ }^{36}$ For the most part any laser whose wavelength rendered it suitable for retinal treatment could also be used to irradiate pigmented tissues in the anterior eye in an attempt to initiate therapeutic processes. In the late 1960s, work had been undertaken using Ruby lasers to induce iridotomies in the treatment of acute closed-angle glaucoma, ${ }^{37}$ and some attempts had been made to irradiate the trabecular meshwork for chronic open-angle glaucoma. ${ }^{38}$
By the late 1970s and early 1980s, extensive research had been carried out to determine which wavelengths were available to target specific areas of the globe. ${ }^{35}$ In summary, ultraviolet radiation was divided into three wavebands, A, B, and C, as also was infrared, and between them fell a single waveband, visible. These somewhat artificial divisions grouped together radiations, which induce similar biological reactions within a given wave band, but which were different from those in other wavebands (Figure 4). In the ultraviolet, there was a somewhat simplistic concept that UVA was all right, UVB burned, and UVC killed. This came about because UVA grouped together the wavelengths that were associated with sun tanning and were therefore deemed to be all right. We now know that UVA should stand for ageing as the wavelengths in this waveband are implicit in the ageing of the skin. UVB grouped together the components of ultraviolent responsible for that which we describe as sun burning, while UVC, up until this time, was used predominantly to kill bacteria. Given my background in laser safety, I was inspecting many industrial sites including some concerned with highresolution lithography using ultraviolet C, Excimer lasers. I was amazed at the way in which such lasers could ablate material with amazing precision and immediately thought of the possibility of using such systems on the cornea. I filed patents ${ }^{39}$ while my dear friend and colleague Stephen Trokel thought of publication and produced the first paper showing the effects of Excimer laser radiation on the cornea in $1983 .{ }^{40}$ There followed several years of active collaboration between us and many publications, which highlighted the potential of a laser system emitting at $193 \mathrm{~nm}$ for refractive surgery. ${ }^{41-43}$

In Excimer lasers, atoms of inert gases are forced to combine transitorily with halogen atoms under high pressure and huge electrical voltages. The combination of argon and fluorine atoms under such circumstances results in a high-energy particle, which is unstable and wants to revert to its component parts as quickly as possible. The photons emitted by this uncoupling have an energy of $6.4 \mathrm{eV}$ and a wavelength of $193 \mathrm{~nm}$. Most biological tissues have bonding energies holding carbon atoms together in the order of $3 \mathrm{eV}$. If such systems are hit by photons from an argon fluoride laser, then the molecular components of the target are uncoupled. At $193 \mathrm{~nm}$ the penetration depth of these high-energy particles is in the order of $0.2-0.25 \mu \mathrm{m}$. Therefore, on irradiation each laser pulse ablates tissue over the entire irradiated area to this depth.

Initially my peers thought to use such systems to carry out radial keratotomy but with infinite control of incision/ablation depth. However, Excimer lasers were unique in that they had very large beam profiles, 


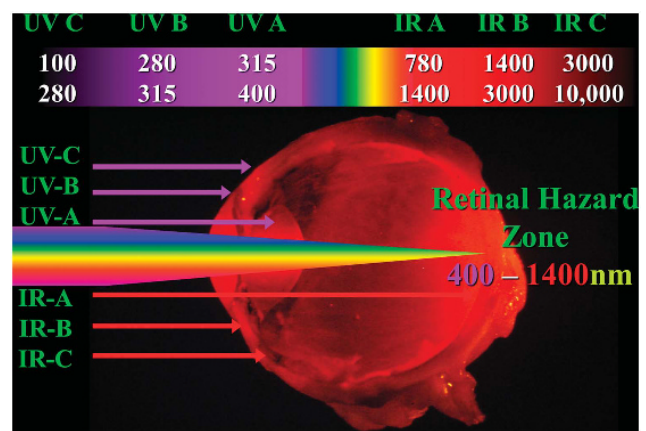

Figure 4 Schematic showing the somewhat arbitrary subdivision of optical radiation into seven wavebands, which separate the radiations into wave breaks within which roughly similar biological effects are elicited, but between the wave breaks effects differ. Ultraviolet (UV) effects are limited to the cornea and lens as a result of their transmission, while visible and infrared (IR) have the potential of reaching the retina and as such are designated the 'retinal hazard zone', which extends from 400 to $1400 \mathrm{~nm}$.

typically $10 \mathrm{~mm}^{2}$, and they did not have to be focused to produce sufficient photon energy to induce a change in tissue, as every photon in the beam could by itself produce a change. As a consequence, my own thoughts and those of Trokel were to use large beams to reprofile the curvature of the cornea. Initially, this was to be achieved by firing the laser through a progressively opening iris diaphragm, thus cutting a stepped 'Greek amphitheatre'-like ablation onto the target surface ${ }^{43}$ (Figure 5). We called this procedure photorefractive keratectomy (PRK). We presented our initial results at the 'First International Workshop on Corneal Laser Surgery' in Berlin in 1980, which we organised with Theo Seiler (Figure 6). At the time we received huge criticism for even considering the concept of interfering with the optical zone of the cornea. At the forefront of these criticisms was the sanctity of Bowman's membrane. We should not interfere with this because 'it was the repository of the elastic memory of the cornea; it was the only way in which a smooth border could be maintained for the corneal epithelium; it was a barrier to diffusion and it was a barrier to infection' - touch this at your peril! Mindful of such criticisms, a first requirement was to determine the relationship between how much tissue was required to be removed and over what area for any given induced dioptric correction. This resulted in a paper, of which I was an author, referred to as the Munnerlyn equation, which was turned down by every major ophthalmology journal for 3 years before being published and acquiring a very high citation index. ${ }^{44}$ Using this equation demonstrated that corrections could be made up to 3D without totally ablating Bowman's membrane, provided a small optical zone was used $(3-4 \mathrm{~mm})$ (Figure 7). This was the reason that the earliest

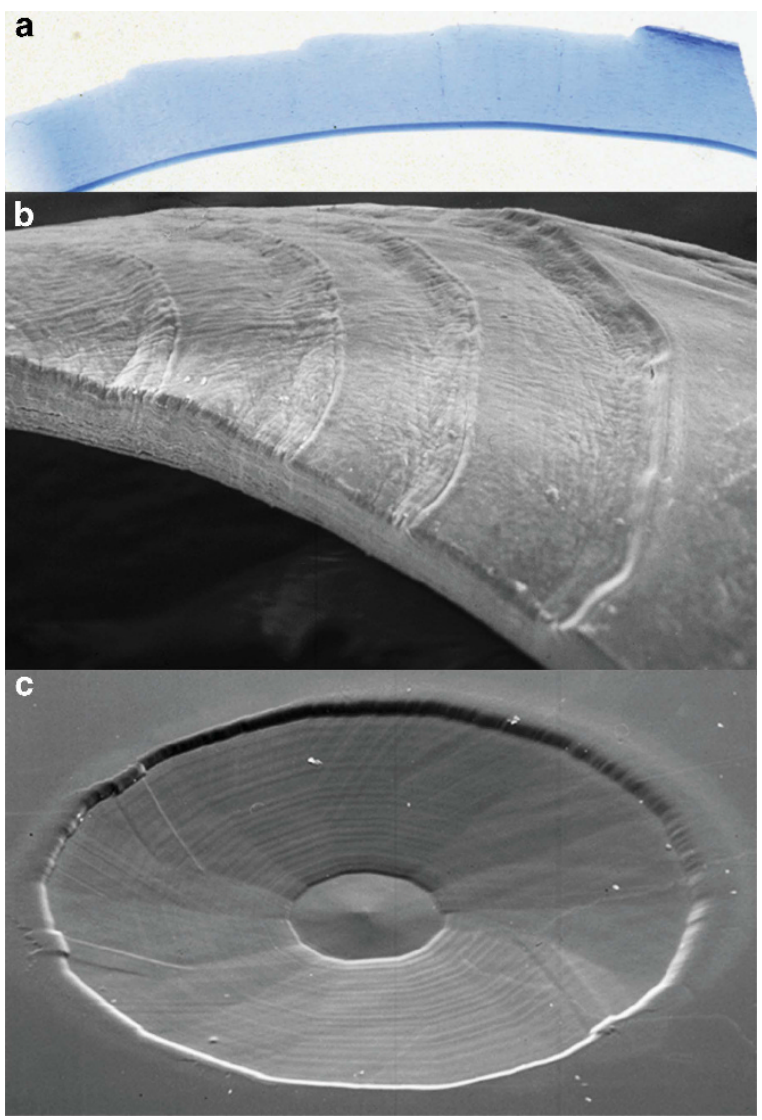

Figure 5 Light and scanning electron micrographs showing the principle of controlled ablation to change the curvature of a substrate. In the light micrograph (a) and the scanning electron micrograph (b), an Excimer laser was directed through a progressively opening aperture (an iris diaphragm) and as a result progressively ablated different areas with the resultant step structure in the surface. By driving such an aperture with a motor under control of a computer, smooth curved surfaces could be produced and are demonstrated in (c).

trials were carried out with small beam diameters, not as revisionist history states because lasers in the early days had small beams. Clinical studies demonstrated that concern about Bowman's membrane was unnecessary because the concepts thought to underlie its functions were erroneous and the surface created by the ablation procedure was sufficiently smooth that the regrowth of epithelium was regular (Figure 7). It should also be remembered that very few species actually possess a Bowman's layer.

The early clinical procedure, termed PRK, ${ }^{43}$ went through a number of trials and iterations of algorithms and after 10 years of experience throughout the world finally received approval from the US Food and Drug Administration in October 1995. Continuous improvement in laser design and algorithms demonstrated that PRK was safe and predictable and could address both spherical and astimatic errors. 


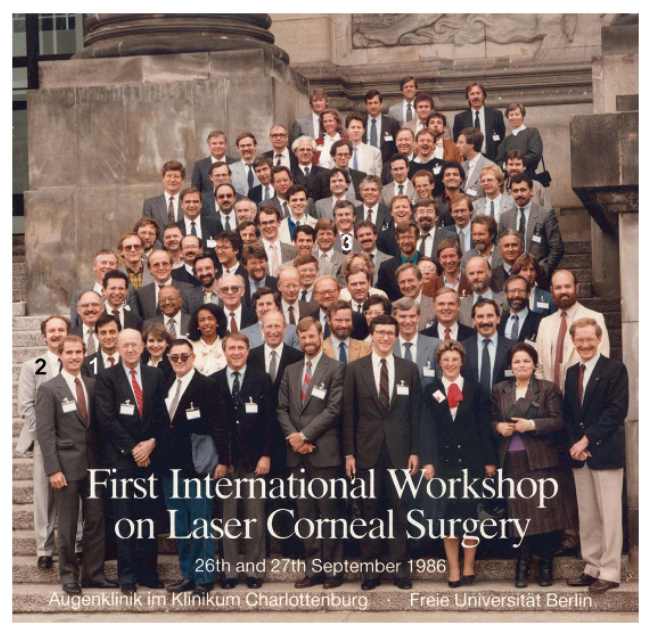

Figure 6 Photograph of the attendees of the First International Workshop on Corneal Laser Surgery in Berlin organised by Steve Trokel (1), Theo Seiler (2), and myself (3). This meeting brought together physicists engineers and a relatively small number of ophthalmologist's, but was the beginning of a new era in refractive surgery as it was here that I first presented large area ablation and effectively brought an end to the era of radial incisions.

The original large beams slowly gave way to systems using computer-controlled flying spots, thus allowing the most complex wave or topography-guided profiles to be ablated. In its earliest iterations, three undesirable observations were made in association with PRK. First, the original small beam profiles resulted in some disturbances, particularly with driving at night, because of the creation of a myopic blur circle. Such complications disappeared with the use of larger beams and blended edge profiles. ${ }^{45,46}$ Second, some patients showed a transitory loss of corneal transparency, termed haze. Trials were carried out using steroids and nonsteroidal anti-inflammatories and more recently mitomycin C. Extensive studies of the causes of haze demonstrated that it resulted from simultaneous injury to the corneal epithelium and underlying stromal keratocytes. ${ }^{47}$ Haze was only a problem in a small percentage of patients and fortunately resolved without medication in a matter of weeks or months in most cases. Control trails demonstrated that while steroids had a marginal effect during the period of application, no significant differences were observed between treatment and controls within 3 months of cessation of treatment. ${ }^{48}$ The third 'complication' was patients complaining of pain because of the removal of the corneal epithelium for the first 8 to $10 \mathrm{~h}$ after cessation of the action of the topical anaesthetic applied before the procedure. ${ }^{49}$ Research demonstrated that if patients were provided with single drop minims of topical anaesthetic sufficient to suppress the pain sensation for $8 \mathrm{~h}$, complaints were reduced significantly.

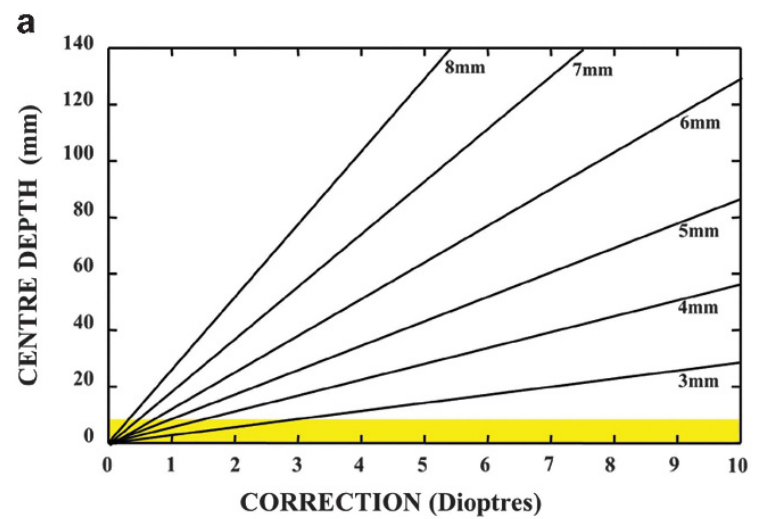

b

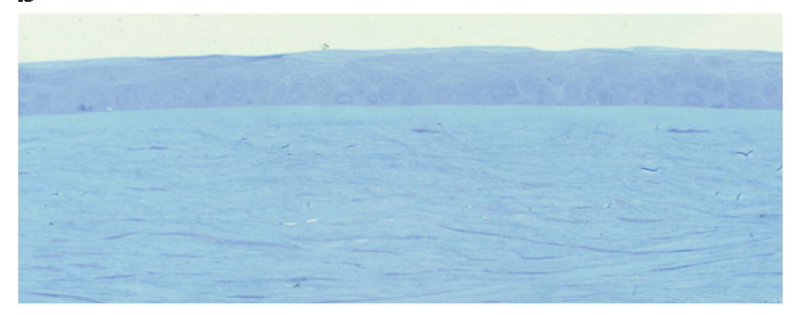

c

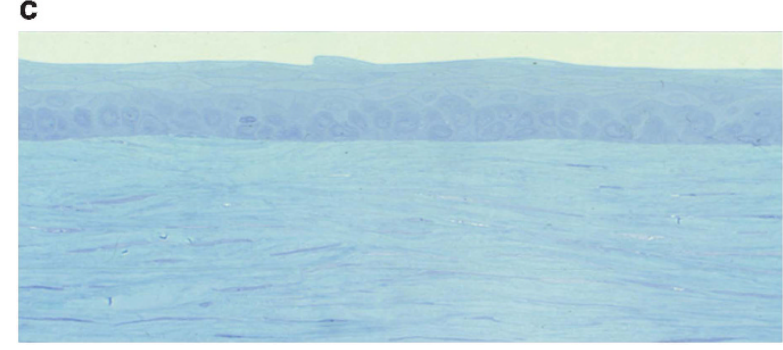

Figure 7 (a) A graphical illustration of the relationship between the depth of ablation required for a given ablation diameter to generate a given dioptric correction. This relationship known as the Munnerlyn formula demonstrated that for very small beam diameters corrections up to $-2.5 \mathrm{D}$ could be achieved without completely ablating through Bowman's membrane (shown in yellow). Attempts to preserve Bowman's membrane in the earliest studies resulted in the use of small beam diameters, but these were rapidly abandoned after extensive laboratory studies showed that the preservation of the membrane was not essential. The postoperative uniformity of the corneal epithelium is demonstrated in a human cornea several weeks after surgery in (c), which compares favourably with an unablated area of the same cornea shown in (b).

I have to confess that my concept for PRK was to minimise the role of the surgeon. I realise that it is not completely comparable, but it is significant that the vast majority of accidents involving aircraft are caused by human error rather than system error. In creating this new form of refractive surgery, my thought was that the surgeon's major role was deciding which patient should not have the procedure. Once a patient had been accepted, their refractive information was entered into the computer controlling the laser, and the surgeon's 
final role was to position the patient's eye under the system and then press the foot pedal. This simplicity obviously appealed to optometrists and in the United States at least three states had given permission for optometrists to carry out PRK. This was obviously of some concern to US ophthalmologists who had waited 10 years to carry out such refractive surgery. They therefore welcomed the advent of LASIK pioneered by Lucio Barrarto $^{50}$ and Ionis Palikaris, ${ }^{51}$ which involved cutting and lifting a flap of corneal stroma, thereby preserving epithelium on a base of Bowman's layer. This was originally conceived as a way of extending the range of refractive corrections, which it failed to do, but was later promulgated as a means of avoiding haze and pain, which it did. LASIK was a surgery and therefore could not be undertaken by optometrists, and it was primarily for this reason that LASIK became the procedure of choice in the United States. Today, both PRK and LASIK are performed with different groups extolling the different virtues of these two procedures. ${ }^{52}$

My major concern about LASIK was not so much that an element of surgical skill with attendant potential risks had been introduced into the technique, but that cutting a flap in essentially normal corneas would alter the biomechanics of the globe. Any engineer would attest to the fact that removing substance from a component of the wall of a pressure vessel, and one exposed to constant flex, would increase the rate of fatigue and bring forward the date of ultimate failure. To this end, I worked with a mechanical engineering colleague, John Tyrer, Professor of Mechanical Engineering at Loughborough, to devise systems for measuring corneal strength. The Loughborough group had a huge experience of interferometry measuring the strengths of bridges throughout the United Kingdom. Victorian bridges built from 1840 onwards were designed for horses and carts, but today carry 40 ton trucks. By contrast, the bridges of the motorway building era of the 1960s are suffering from 'concrete cancer' and are in danger of collapse, for example, the Hammersmith Flyover. The Loughborough group have used a noninvasive optical technique using laser interferometry to produce strain maps of the bridges with and without loads, thereby identifying potential weaknesses. ${ }^{53}$ The same techniques have been used in the assessment of aircraft tyres. ${ }^{54}$ In radial tyres, the essential strengthening component is steel wires in a rubber matrix. This is in many ways analogous to the corneal stroma whereby collagen fibrils run in a glycosaminoglycans (GAGs) matrix and the mathematics required to analyse the strain maps have similarities.

These studies demonstrated that first there was a natural age-related stiffening of the cornea induced by progressive crosslinking associated with collagen ${ }^{55}$

(Figure 8). Second, rigidity in the cornea was heterogeneous with the outer layers being more rigid than the inner layers. ${ }^{56}$ Typically, Bowman's layer was the strongest followed by the anterior third of the cornea, while little strength was implicit in the posterior twothirds. Third, the flap created in LASIK weakened the cornea and the magnitude was related to the depth of the incision. ${ }^{57}$ Empirical studies on human cadaver corneas also demonstrated that the bed of the flap or delamination of the lamellae alone had little or no effect on corneal strength. By contrast, the edge cuts alone, that is, down through the lamellae weaken the cornea as much as a full LASIK procedure. ${ }^{58}$ In the early days of LASIK, flaps were typically created at 140-160 $\mu \mathrm{m}$ depth. At such depths, between 25 and $30 \%$ of the corneal strength was lost and this was never to be recovered. Replacement of the flap and subsequent wound healing a

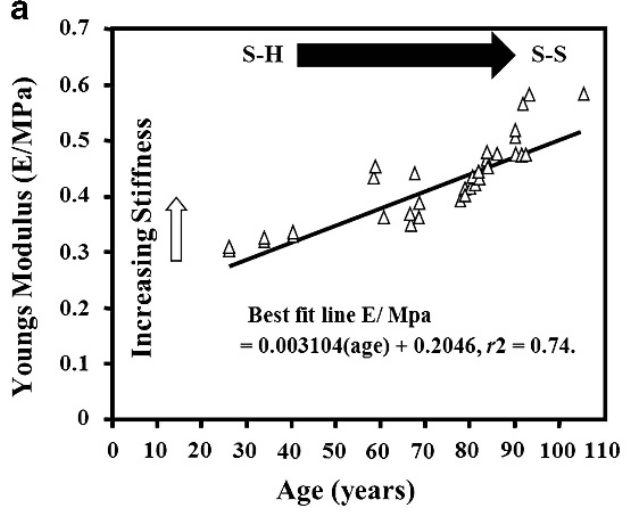

b

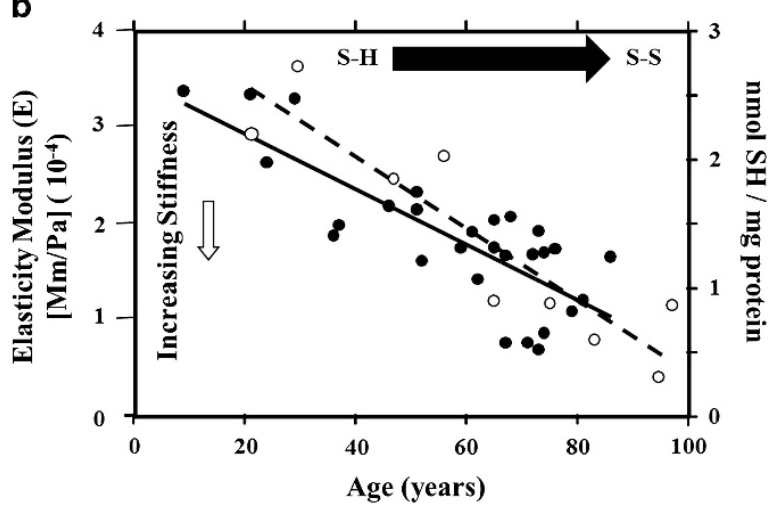

Figure 8 Graphs showing the change in elasticity as a function of age in the cornea (a) and Bruch's membrane (b). In the cornea, the change is measured in terms of Young's modulus of elasticity as it is thought to reflect changes in the bond structure of the tissue with age, particularly the collagen. The reversal of the slope seen in (b) is as a consequence of measuring elastic moduli and not Young's modulus (open circles). In the retina, it was possible to use a fluorescent technique to determine quantitatively the decrease in the number of fluorescent SH bonds, which are flexible and gave a measure of the non-fluorescent rigid SS bonds (closed circles). 
did not result in any fibres crossing the line of the incision and flaps can be lifted many years after surgery. These findings led to a movement towards thinner and thinner flaps. ${ }^{59}$ At $100 \mu \mathrm{m}$, flaps still reduced corneal strength but only by around $10 \%$ and thin flaps are now the norm.

Increasing concern about weakening corneal strength has led to two further developments, interstromal lenticular removal and crosslinking. In the former, for example, small incision lenticular extraction (SMILE), a femtosecond laser cuts a predetermined refractive element in the corneal stroma and this is extracted via an access channel. ${ }^{60}$ In this technique, because most of the anterior stroma and Bowman's membrane are preserved and only a small channel is cut down through the superficial layers to extract the lenticule, biomechanical disturbances are thought to be minimal, although still present.

The concept of crosslinking was introduced by Theo Seiler, ${ }^{61}$ who showed that soaking the cornea with riboflavin for $30 \mathrm{~min}$ followed by $30 \mathrm{~min}$ exposure to ultraviolet radiation $(370 \mathrm{~nm})$ at $3 \mathrm{~mJ} / \mathrm{cm}^{2}$ increased corneal rigidity in patients with Keratoconus. Using interferometry we were able to verify in human corneas in vitro that rigidity was increased by three to four times. ${ }^{62}$ Biological tissues absorb energy not power and within a given time domain there is a reprocity, so we introduced a regime whereby corneas had a brief exposure to riboflavin, $1-6 \mathrm{~min}$ followed by $3 \mathrm{~min}$ exposure to ultraviolet radiation at $30 \mathrm{~mW} / \mathrm{cm}^{2}$. This accelerated exposure technique delivered the same energy to the cornea as the $3 \mathrm{~mW}$ for $30 \mathrm{~min}$ and produced identical biomechanical results, but obviously significantly reduced treatment times. Given that $100 \%$ of LASIK eyes were weakened by the procedure and that $100 \%$ of crosslinked eye are strengthened, a new technique was proposed termed LASIK Xtra whereby after lifting the flap and carrying out the laser exposure the surface of the bed was flushed with riboflavin for $1 \mathrm{~min}$, rinsed, the flap replaced, and then the eye exposed to UV radiation at $30 \mathrm{~mW} / \mathrm{cm}^{2}$ for $1 \mathrm{~min} .{ }^{63}$ To date, this procedure has resulted in a further reduced scatter of intended $v s$ achieved corrections and has allowed a significant increase in range of corrections attempted. Presumably, these observations relate to increased rigidity in the postoperative site and a transient increase in the stability of the flap interface. However, a more exciting development of crosslinking is the potential to topographically crosslink corneas using complex algorithms developed from biomechanical measurements. ${ }^{64}$ Such procedures are now being undertaken with promising results and the advantage that for the first time a refractive surgical procedure may be undertaken without any weakening as a result of cutting tissues. ${ }^{65}$ Crosslinking actually strengthens the corrected eye. It also has the potential of being carried out without endothelial removal and therefore without pain. It is of interest that $95 \%$ of myopes in the United Kingdom have a correction of $-3.5 \mathrm{D}$ or less, while at present $95 \%$ of refractive surgery is undertaken on those with a correction of $-4 \mathrm{D}$ or greater. It could be that the $95 \%$ of potential candidates not presenting for current refractive surgery may well reconsider when topographic crosslinking, termed photorefractive intrastromal crosslinking (PiXL), ${ }^{66}$ has passed through current clinical trial phases.

Crosslinking is a natural process occurring throughout the body but is particularly reflected in acellular membrane systems. In the eye loss of elasticity is seen not only in the cornea but also in Bruch's membrane, ${ }^{55,67}$ where increasing stiffness occurs as a function of age resulting from the progressive conversion of flexible $\mathrm{SH}$ bonds to inflexible SS bonds. The SH bonds or thiols can be identified using a technique to exploit their fluorescence, and as a function of age decreasing fluorescence is a measure of increasing SS bonds. This process is directly related to the increased stiffening in the membrane system as can be demonstrated by quantitative measures of elasticity (Figure 8). Almost all of this crosslinking is associated with either the collagen helixes or their matrix of GAGs. Ageing is the highest risk factor in the onset of age-related macular degeneration and all of us regardless of genotype will suffer some form of retinal degenerative changes during the latter part of our lifetime.

At a cellular level, our bodies may be divided into two, being composed of those systems whereby cells are constantly replaced and those where cells are formed during embryogenesis, and remain with us for our lifetime. In the former, ageing may be considered as a process whereby cell death slowly reaches a point where it exceeds cell renewal. By contrast, in postmitotic cells ageing has to be considered as a process whereby cell life is regulated by the underlying genetically determined ageing curve of a given individual, coupled with lifestyle and environmental exposure. Normally in cell systems exposed to high environmental stress such as sunlight and ultraviolet radiation, for example, the surface of the skin, cells have a short lifetime and a rapid turnover. Uniquely the cells of the retina are irradiated throughout our lives by optical radiation between 400 and $1400 \mathrm{~nm}$ and do not divide. In the outer retina wall, lightabsorbing photoreceptor cells and retinal pigment epithelium are adjacent to an enormous concentration of oxygen in the choroid. Light and oxygen are a recipe for the generation of reactive oxygen species, which are highly toxic to biological systems. In the 1960s, it was discovered that while the photoreceptor cells themselves 
do not divide and renew, they do constantly regenerate their light-sensitive membranes. This work of an earlier Bowman lecturer Richard Young (1982) ${ }^{68}$ showed that on an hourly basis in rods three to five new membranes are made in the region of the cilium and displace older discs towards the retinal pigment epithelium. Rod outer segments are prevented from an exponential growth by shedding packets of 30 or more discs into the retinal pigment epithelium on the onset of light every morning. This exquisite system of disc shedding of our night-time detectors first thing in the morning is complemented by disc shedding $4 \mathrm{~h}$ into the sleep period by our daytime photoreceptors. Unfortunately, this huge biomass presented to the retinal pigment epithelium, which in this case is acting like a captive macrophage, which begins to overwhelm the degradative activity of these cells. In midlife, debris is seen to build up within the pigment epithelial cells, much of which is seen as the autofluorescent pigment lipofuscin. ${ }^{69}$ At the same time that this buildup of waste products is observed within the pigment epithelium, waste products are also seen to be accumulating within the inner collagenous layer of Bruch's membrane. ${ }^{70}$ Healthy retinal pigment epithelium and Bruch's membranes are a prerequisite for healthy photoreceptor cells because all their nutrients must come from the choroidal circulation via free diffusion across Bruch's and then active transport across the pigment epithelium. At the same time, the water relationships of the retina are governed by pumps in the retinal pigment epithelium actively removing water from the neural retina into the choroidal circulation. In addition to its role in absorbing stray radiation that has passed through the photoreceptor cells, the pigment epithelium is acting as a hugely active macrophage and at the same time as an 'effective vascular endothelial' cell. Any process that compromises either the retinal pigment epithelium or Bruch's membrane will compromise nutrients into and water out of the system. ${ }^{19}$ The paradox is therefore presented that in order for the photoreceptor cells to last a lifetime, they have to generate a constant supply of membranes, which in turn clog both the retinal pigment epithelium and Bruch's membrane with waste products. A large proportion of the waste material passing into Bruch's membrane is lipid rich and as a consequence hydrophobic. This led to another Bowman lecturer, Alan Bird (2002) and myself suggesting that it presented a potential barrier for water passing out of the neural retina and could therefore be a major component in the generation of pigment epithelial detachments. ${ }^{71}$

Subsequent work in our laboratories demonstrated that there was a progressive decrease of water movement, termed hydraulic conductivity, through the system as a function of age. ${ }^{72,73}$ The rate of loss was greater in the macular zone than in the peripheral retina. The half-lives of the exponential decay were 16 and 23 years, respectively, with a crucial threshold being reached at just over 100 years, where the system barely managed to allow sufficient water to exit and was very close to collapse (Figure 9). In the few specimens examined from AMD eyes, the system began to crash even earlier. The laboratory studies were also able to demonstrate that similar but linear decays occurred in the ability of amino

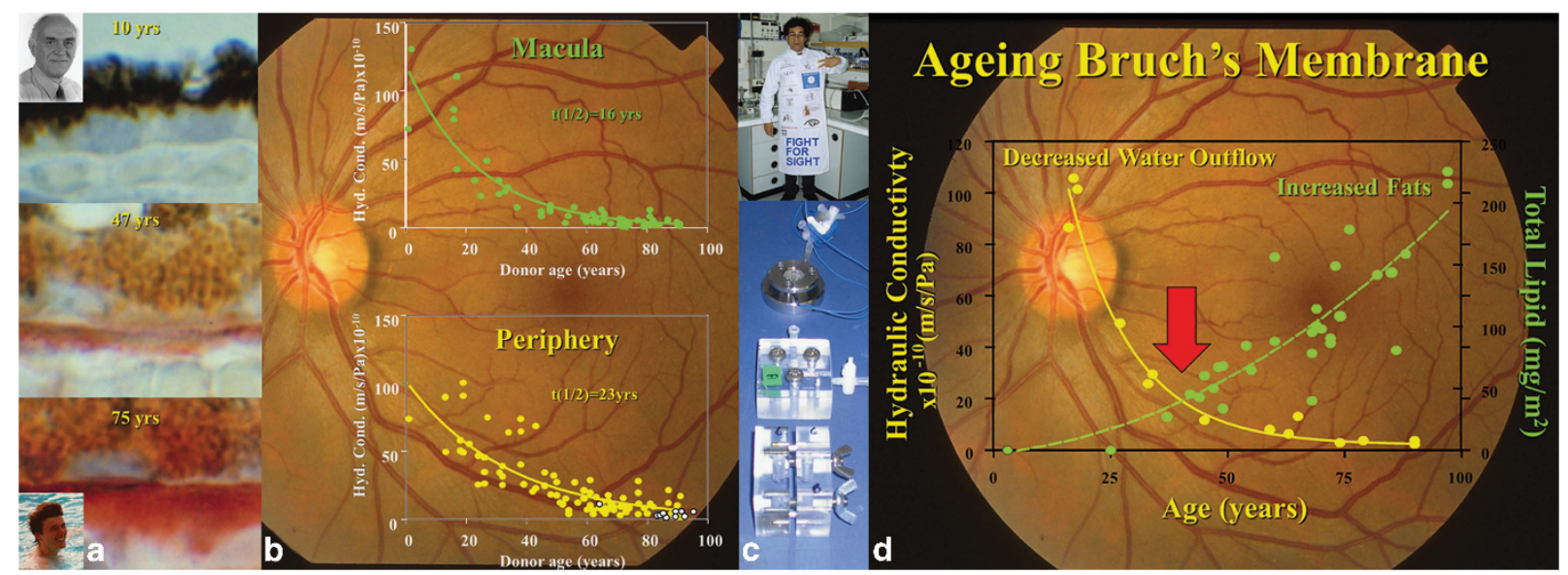

Figure 9 This figure summarises the anatomical and physiological ageing changes in Bruch's membrane. (a) Histochemical staining of Bruch's membrane using Oil Red O on membranes from tissue derived from individuals 10, 47, and 75 years old, respectively. The study undertaken with Alan Bird and Daniel Pauleikhoff demonstrated that a progressive increase in lipid deposition in the membrane is functional age. The functional implications of changes in the tissue are demonstrated in (b) for both the macular and peripheral regions of the retina. On examining the transport of water through isolated membranes, hydraulic conductivity, an exponential decay in the ability of water to pass through the system was determined and the rate of loss of transport was faster in the macular than in the periphery. This work was conducted with Ali Hussein (c) using highly modified Ussing Chambers. (d) The apparently contradictory evidence of maximum loss of hydraulic transport occurring at a time of negligible deposition of lipids. 
acids and macromolecules to passage through the membrane. In the case of macromolecules, the diffusion limit remains constant as a function of age at around 75 to $80 \mathrm{kDa}$, but the diffusion rate slows down significantly, again with a faster rate of decline in the macular zone than in the periphery. ${ }^{74}$ It was also interesting to note that the major element of loss in hydraulic conductivity occurs before the age of 40 years, while the major buildup of lipid debris occurs from 40 years onwards; therefore, further investigations of the ageing processes within Bruch's membrane were initiated (Figure 9).

Acellular membranes are regulated by balanced processes involving matrix metalloproteinases (MMPs) and tissue inhibitors of matrix metalloproteinases (TIMPs) and both of these systems have been found to be present within Bruch's membrane ${ }^{75}$ (Figure 10). An excess of the enzymes would result in membranes becoming progressively thinner while an excess of the inhibitors would result in the opposite. In Sorsby's inherited retinal dystrophy, there is a defect in the TIMP3 gene, ${ }^{76}$ and this results in a massive increase in the thickness of Bruch's membrane, such that 18-year-old sufferers have a thickness equivalent to normal individuals in the seventh, eighth, or ninth decade of life. ${ }^{77}$ This increase in debris within Bruch's could be considered to be premature ageing. The concentrations of MMPs 2 and 9 were shown to increase with age in the normal Bruch's membrane as would be expected as a counterbalance to ageing and the increase in debris (Figure 11). ${ }^{75}$ However, such overall increases were deceptive as when experiments were undertaken to discriminate between active and bound forms of the enzymes, it was shown that over the age of 30 years there was an exponential increase in the bound form being sequestered in high-molecular-weight aggregates. ${ }^{78,79}$ This leads to a feedback reaction whereby increased polymerisation of pro-MMP 2- and 9-derived aggregates create a greater disposition of high-molecular-weight species and a reduction in active MMPs, which in turn results in further diminished matrix turnover. Ultimately in the presence of divalent ions, these large macromolecular complexes become trapped within the membrane. Thus, crosslinking of the structural elements are further exacerbated by the progressive deposition of higher and higher molecular weight aggregates. These protein-rich deposits may account for some of the early a Remodelling of Extracellular Matrix
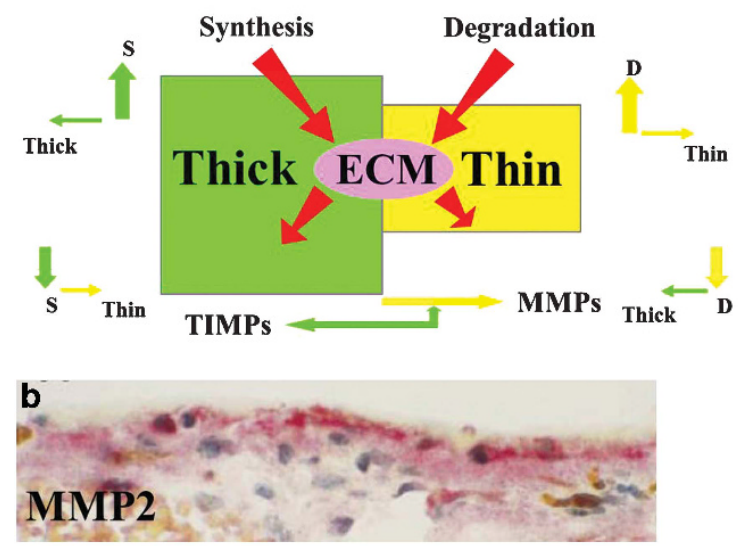

Li Guo, Ali A. Hussain, G. Astrid Limb, and John Marshall, IOVS vol $402676-26821999$

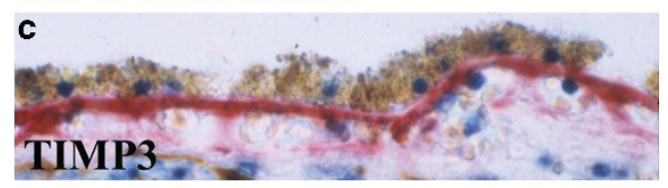

Disturbance of Regulation

- TIMP-3 gene mutations in Sorsby's fundus dystrophy (SFD) (Webber BHF. et al. Nature Genetics 1994;8,352-355)

- TIMP-3 increase in ageing Bruch's (Fariss RN, et al. Am J Pathol 1997;150,323-328)

- TIMP-3 increase in Bruch's in AMD (Kamai M and Hollyfield JG. 1999;40,2367-2375)

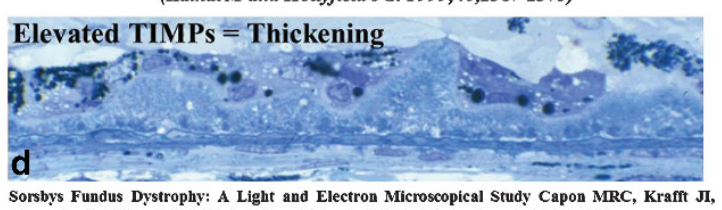

Sorsbys Fundus Dystrophy: A Light and Electron Microscopical Study Capon MR
Alexander RA Hiscott, P.S, Bird, A.C. and Marshall J. Ophthalmology 3: 11-29.1989.

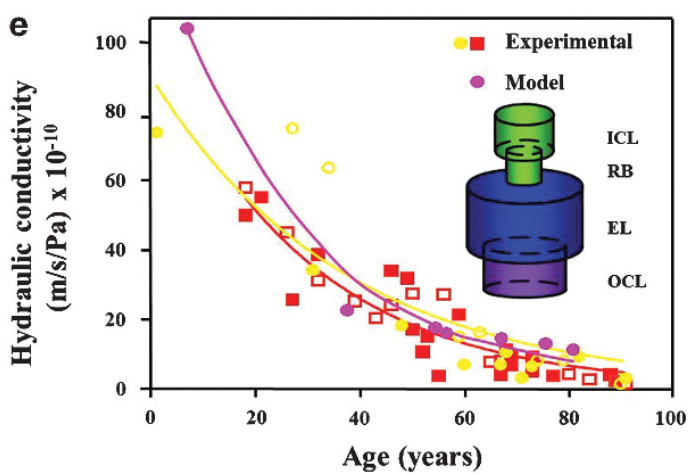

Figure 10 Throughout life, the components of extracellular matrix are regulated by a balance process with MMPs removing excess tissue while under the control of TIMPs (a). The presence of these two systems within Bruch's membrane is demonstrated in the histochemical preparations ( $b$ and $c$ ). Examples of disturbance of this regulatory mechanism have been identified particularly in Sorsby's fundus dystrophy where a genetic defect in TIMP-3 leads to a rapid increase in membrane thickness (d). By studying the movement of water through membranes as a function of age using a variety of different methods, it has been possible to derive both a graphic and mathematical model of resistance in the membrane and to demonstrate that the point of highest resistance occurs at the junction between the inner collagenous layer and the layer of elastin (RB) (e). 
a
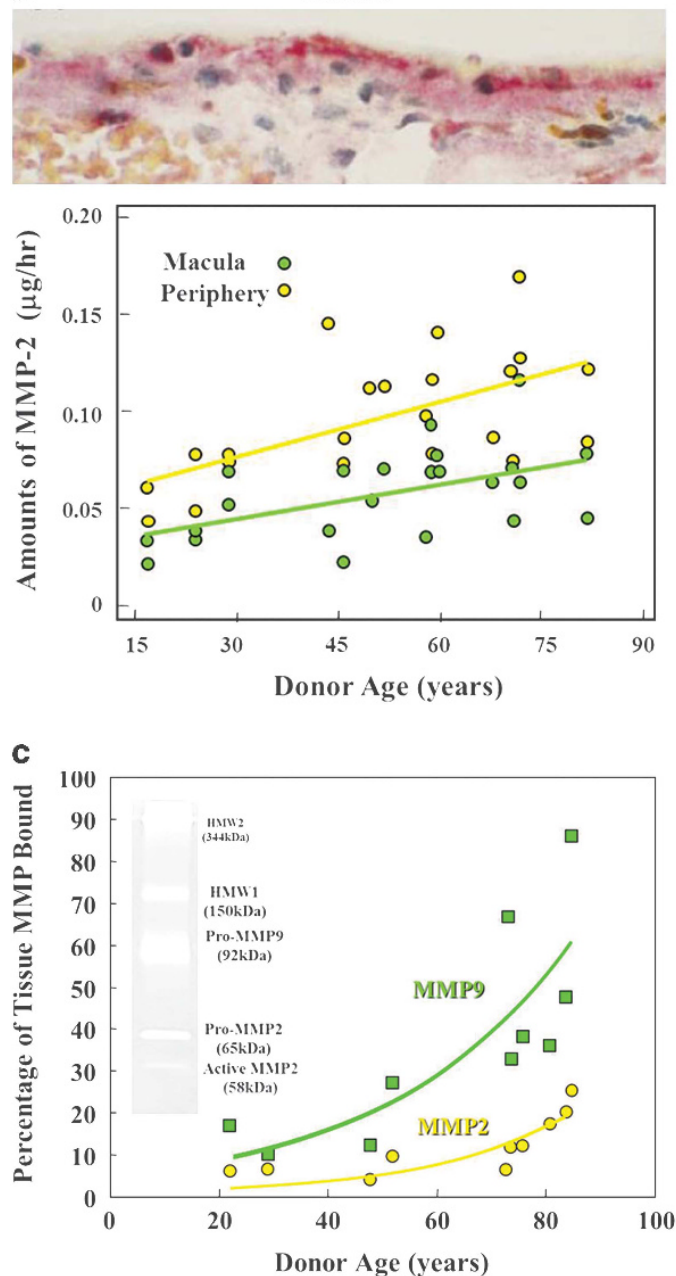
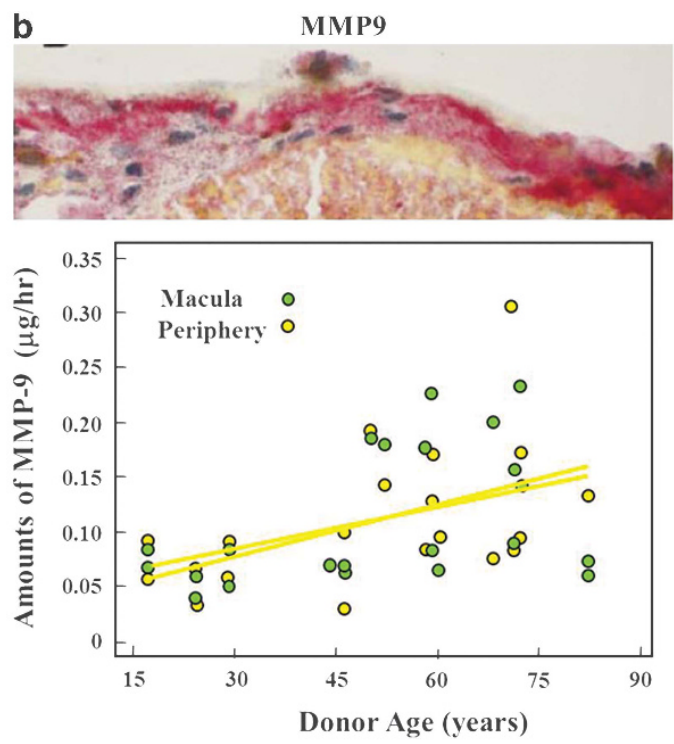

Figure 11 Histochemical staining and biomechanical analysis have shown that as expected the total amount of MMPs 2 and 9 increase as a function of age, presumably in an attempt to maintain the thickness of Bruch's membrane during the ageing process ( $a$ and b), respectively. However, when the active forms of these MMPs were determined, they were clearly shown to decrease as a function of age as a result of binding or sequestration (c).

changes in the hydraulic conductivity of the membrane by effectively decreasing the available space for the passage of water through the system. The potential importance of this underlying process as a factor in the aetiology of age-related macular degeneration is shown in Table 1, where it can be seen that there is a significant increase in total high-molecular-weight elements in AMD as compared with age-matched normal controls. The feedback effect on enzyme capacity is seen in the lower portion of the table where the concentration of active MMPs 2 and 9 are significantly reduced in AMD eyes compared with their age-matched controls.

In experiments where hydraulic conductivity in elderly eyes was measured prior and subsequent to the collation and removal of divalent ions, hydraulic conductivity improved significantly. ${ }^{80}$ This observation throws some doubt as to the credibility of zinc supplementation in AMD patients. Bruch's membrane has the highest concentration of zinc of any tissue in the body, and as our empirical data has shown its removal in the elderly enhances transport mechanisms. Is it really helpful as an addition in the current AREDS regime? ${ }^{81}$

In 1982 in a chapter in the book edited by Garner and Klintworth, we postulated that there were at least 11 sites where anomalies or failure could result in photoreceptor cell degeneration (Figure 12).$^{82}$ Subsequent work particularly in the field of molecular genetics has shown gene defects in each of the potential mechanisms that we postulated and of these at least six manifest in Bruch's membrane. To date, the current therapeutic approach to the retinal dystrophies has been either gene therapy targeted to address the specific problem in each condition $^{83}$ or the promise of stem cell therapy with the replacement of specific cell systems. ${ }^{84}$ In AMD it should 
Table 1 Gelatinase activity in peripheral samples of Bruch's choroid in control and AMD donors

\begin{tabular}{|c|c|c|c|c|c|}
\hline MMP species & Donor group & Free & Bound & Total & \\
\hline \multirow[t]{2}{*}{ HMW2 } & Control & $1435 \pm 1520$ & $12702 \pm 3940$ & $14137 \pm 4725$ & High bad \\
\hline & AMD & $6685 \pm 5444^{*}$ & $15195 \pm 3018$ & $21880 \pm 8182^{*}$ & Low good \\
\hline \multirow{2}{*}{ HMW1 } & Control & $1335 \pm 2470$ & $5996 \pm 2911$ & $7331 \pm 4040$ & \\
\hline & AMD & $6327 \pm 7064^{* *}$ & $10480 \pm 5616$ & $16807 \pm 11950^{*}$ & \\
\hline \multirow[t]{2}{*}{ Pro-MMP-9 } & Control & $9354 \pm 11895$ & $16068 \pm 7692$ & $25422 \pm 16553$ & \\
\hline & AMD & $33375 \pm 25579^{* * *}$ & $22572 \pm 7274$ & $55947 \pm 30662^{*}$ & \\
\hline \multirow[t]{2}{*}{ Pro-MMP-2 } & Control & $1567 \pm 1753$ & $1393 \pm 964$ & $2960 \pm 2071$ & \\
\hline & AMD & $379 \pm 374^{*}$ & $674 \pm 700$ & $1053 \pm 854^{*}$ & \\
\hline \multirow[t]{2}{*}{ Active MMP-9 } & Control & NDet & $517 \pm 376$ & $517 \pm 376$ & High good \\
\hline & AMD & & $195 \pm 80^{*}$ & $195 \pm 80^{*}$ & Low bad \\
\hline \multirow[t]{2}{*}{ Active MMP-2 } & Control & $357 \pm 428$ & $1978 \pm 1140$ & $2336 \pm 1257$ & \\
\hline & AMD & $335 \pm 519$ & $614 \pm 534^{* * *}$ & $949 \pm 885^{*}$ & \\
\hline
\end{tabular}

$* P<0.05$.

$* * P<0.01$

$* * * P<0.005$.

This table demonstrates the effect of sequestration of MMPs into high-molecular-weight complexes as a function of age and disease. In AMD, the species of high-molecular-weight are significantly elevated above those of controls. By contrast, active MMPs 2 and 9 are significantly reduced when compared with controls. Bold highlights good vs bad.

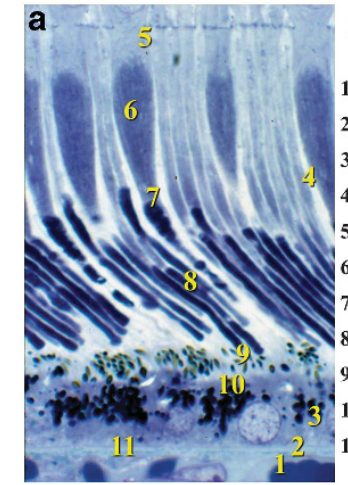

Pathology of Photoreceptor Cell Degeneration

1. Extra ocular factors

. Abnormal Bruch's Membrane Transport

3. Transepithelial transport defect

4. Epithelial to photoreceptor donor defect

5. Abnormal receptor sites

6. Micrometabolism malfunctions

7. Faulty membranogenesis

. Inability to stabilise membranes

9. Malfunction in phagocytosis

10. Malfunction in lysis

11. Inability to void lytic products
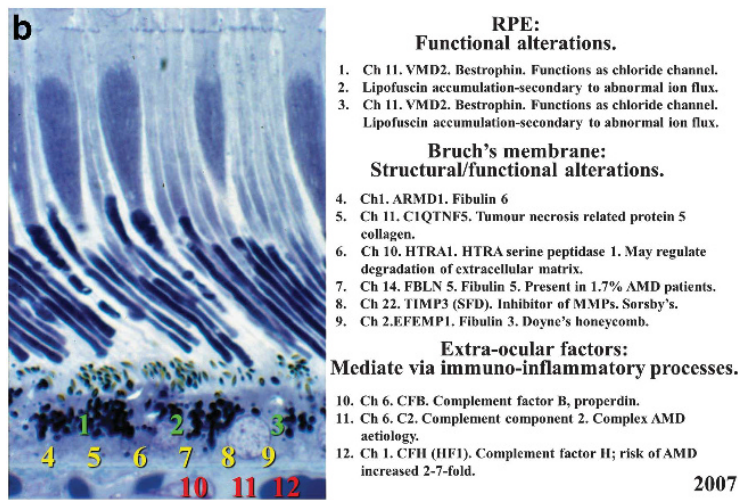

Figure 12 The theoretical locations of potential errors in photoreceptor cell maintenance that could result in degeneration were postulated by myself and Alan Bird in 1982 (a). Subsequently determined genetic faults in the system and their locations are shown in (b) and confirm the previous postulations with a significant number having expression of defect within Bruch's membrane. be remembered that the biggest risk factor is ageing and in the outer retina the most significant ageing relates to crosslinking and debris accumulation including drusen in Bruch's. ${ }^{85}$ It would seem therefore that introducing stem cells or gene therapy to a site whose transport mechanisms are irrevocably compromised would be doomed to failure. It would be analogous to planting seedlings in the desert. My thoughts therefore were, would it be possible to rejuvenate Bruch's membrane and to some extent restore its useful transport properties. We had demonstrated that in vitro exogenously applied concentrations of MMPs 2 and 9 improved hydraulic conductivity with the latter showing significant increases. ${ }^{86}$ Earlier work had also shown that subsequent to laser irradiation and associated with the migration of pigment epithelial cells 4 to 7 days after exposure, there was a transient increase in both MMPs. ${ }^{87}$ With conventional lasers available at the time such irradiations would have been counter-productive because the heat flow from the retinal pigment epithelium would cause primary damage to the photoreceptor cells, thereby destroying the element that is essential to preserve. ${ }^{35}$ Commercially companies have been moving towards reducing the time duration of laser pulses to limit heat flow and collateral damage to surrounding tissues. Clinically this concept is seen in the development of MicroPulse lasers, but unfortunately even with a pulse duration of $100 \mu$ s heat flow still reaches the tips of the photoreceptor cells. A further reduction in pulse duration was seen in the work emanating from the Lübeck Laser Centre with a 1 to $10 \mu$ s exposure from an 
Nd YLF laser. ${ }^{88}$ Clinical studies showed further sparing of photoreceptor cells, but the laser itself was extremely large, not very reliable, and its expense probably has impeded its commercial availability.

Given the specific aim of causing the release of a sufficient concentration of MMPs to initiate large-scale rejuvenation of Bruch's membrane while at the same time causing no damage to overlying photoreceptor cells, we designed a novel laser termed 2RT. ${ }^{89}$ The system had to initiate as large an area of pigment epithelial migration as possible while at the same time preserving transport processes to sustain the overlying photoreceptor cells. To avoid the problem of thermal relaxation time and heat conduction, a nanosecond pulse was chosen. In the past nanosecond systems have been used for disrupting the lens capsule in the presence of posterior capsular occlusion (PCO). This process involved bringing the laser beam to an acute focus whereby so many photons were compressed into a short space and time that a huge electric field vector was generated and the target molecules were literally ionised in a plasma. Previous work on laser safety had shown that the safety margin between inducing a retinal lesion and a subretinal haemorrhage reduced from a factor of about 10 to 1 in the case of millisecond pulses to 3 to 1 with nanoseconds. ${ }^{32}$ From these data it was apparent that the beam should not be brought to a focus because of this potential problem and therefore the system was designed to have a $400 \mu \mathrm{m}$ spot size. However, if $400 \mu \mathrm{m}$ diameter of pigment epithelium were damaged then a large area of photoreceptor cells will be deprived of nutrients until such lesions had healed. A second novel feature was therefore incorporated into the system whereby the beam energy distribution was made discontinuous with only a small percentage of the beam capable of raising cells above the damage threshold. This could be considered as enhancing the speckle of the laser beam. In the past manufacturers have tried very hard to reduce noise in their beams to produce as best they could either a 'top hat' or a Gaussian energy distribution. In this system, the reverse was required and it was hoped that the system would have randomly distributed hotspots involving no more than $15 \%$ of the total area irradiated. The hotspots had to be sufficiently far apart that there was no large area of cell loss anywhere within the target area. This configuration would maximise the borders from which RPE cells could migrate while at the same time maintain large areas surrounding the spots, which would facilitate transport to the overlying photoreceptor cells. This concept is illustrated in (Figure 13). Further therapeutic advantages for retina would be a mild immune response facilitated by the transient loss of blood retinal barrier and a period of cytokine release, particularly 7 to 11 days after exposure associated with pigment epithelial cell

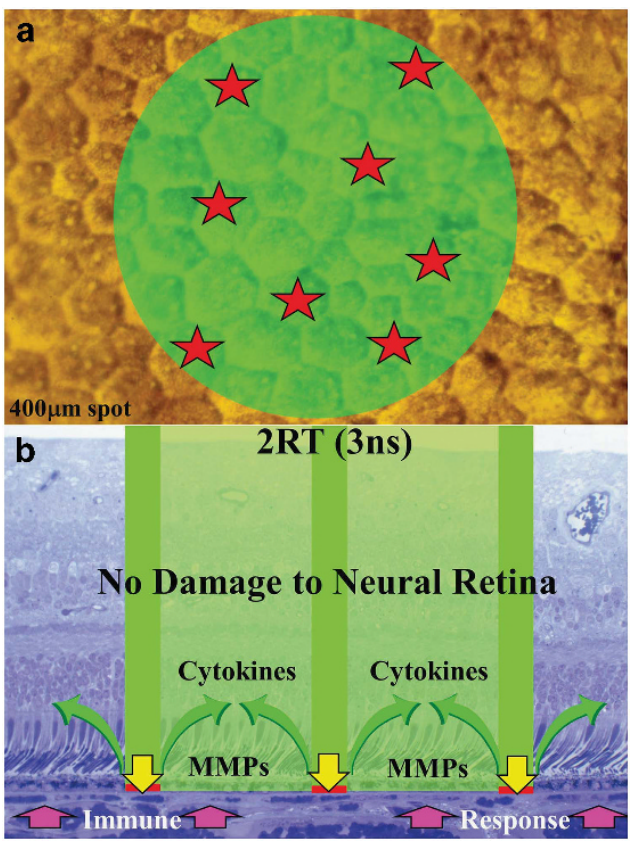

Figure 13 The concept of utilising a nanosecond pulse duration for retinal treatment required the irradiation to be delivered over a relatively large area to forwarded subretinal haemorrhages resulting from breakage of Bruch's membrane. Large areas of irradiation would have resulted in transport insufficiency for the overlying photoreceptor cells while the pigment epithelium healed. This problem would be avoided by rendering the beam to have a discontinuous distribution of super-threshold hotspots, thereby damaging only between 15 and $20 \%$ of the irradiated cells (a). The damage resulting from such discontinuous distribution and also short pulses would cause a transient break in the outer blood retinal barrier with an associated mild immune response together with release of both MMPs to clean up Bruch's membrane and the release of cytokines into the neural retina (b). These therapeutic elements would not be confounded by secondary degeneration of photoreceptor cells because the discontinuous nature of the cells disrupted by radiation would always allow sufficient cells surrounding them, which had not been changed in any way and could supply the photoreceptor cells with required metabolites during the wound healing period.

division. ${ }^{90}$ A pilot clinical trial using the system in patients with macular oedema demonstrated the efficacy of the system with a rapid clearance of fluid from the neural retina and no loss of photoreceptor cell function associated with the location of any of the lesions, as demonstrated by microperimetry. ${ }^{91}$ A significant number of patients showed improvement of visual acuity. In two further trials carried out on patients with early AMD problems were identified with both the laser system and the trial design. The Australian trial ${ }^{92}$ initially only delivered 12 lesions at clock hours around the macula. They noted clearance of drusen but no measurable change in visual acuity. Any calculation of the yield of MMPs released from such a small number of lesions 
demonstrates that this was potentially gross under treatment. This trial also demonstrated the problem of determining a useful measure of success given that patients entered the trial with a reasonable visual acuity which most retained but which did not improve posttrial. In future studies it would be helpful to incorporate measures of photoreceptor cell function such as fundus densitometry or focal flash recovery time. The Kings College/Moorfields Eye Hospital trial using up to 100 lesions was suspended because the laser supplied did not allow us to reduce energy levels to that which we required and the beam energy distribution was not sufficiently discontinuous. Even with such limitations a significant number of patients showed improved visual acuity at 6 months but did not sustain it at 12 months. This work will continue shortly as a suitably modified laser system has been developed and in future trials the use of an even greater number of lesions will be considered as will retreatment at 3 to 6 months. Even with the disappointing limitations of the lasers commercially supplied, the clinical results complemented those obtained in the laboratory and certainly merit further trials with appropriate laser design. Clearly, lasers can achieve clearance of the debris in Bruch's membrane and this is a fundamental requirement to minimise the ageing risk factor in outer degeneration. If debris clearance is managed at an early stage either with lasers or pharmacological agents, many patients may be saved from the problems of neovascular AMD. The current climate using Avastin and Lucentis is not treating AMD but a late-stage complication and happens to do better than the natural history of the final stages of the disease process. It would obviously be far better to have early intervention with perhaps rejuvenation of Bruch's membrane in our early 40s, thereby delaying the ageing processes sufficiently to sustain vision throughout life. Even if a genetic defect is present, delaying the rate constants of the underlying ageing processes may ensure that the combined effect of the two components is not manifest during the patient's lifetime.

I hope that I have demonstrated that lasers have had an obvious and significant impact on the two acellular membranes that I have discussed thus far. For completeness I should add that lasers are now having a role in corneal grafting procedures and particularly in those involving Descemet's membrane where the precision of cutting is beginning to revolutionise surgical techniques. The beginnings of this process were discussed in Gotfried Naumann's Bowman lecture $(1994)^{93}$ and more recent advances are now in the literature. ${ }^{94}$ They have for some time played a role in the management of PCO with the advent of the YAG laser. ${ }^{95}$ Changes in intraocular lens materials and lens design, particularly edge profiles, have significantly reduced the instance of PCO in adults; ${ }^{96}$ however, the problem is still significant in children. The wound healing capacity of the lens epithelial cells in paediatric cases almost always leads to multiple procedures. In a recent understanding of cellular dynamics, a promising new approach has

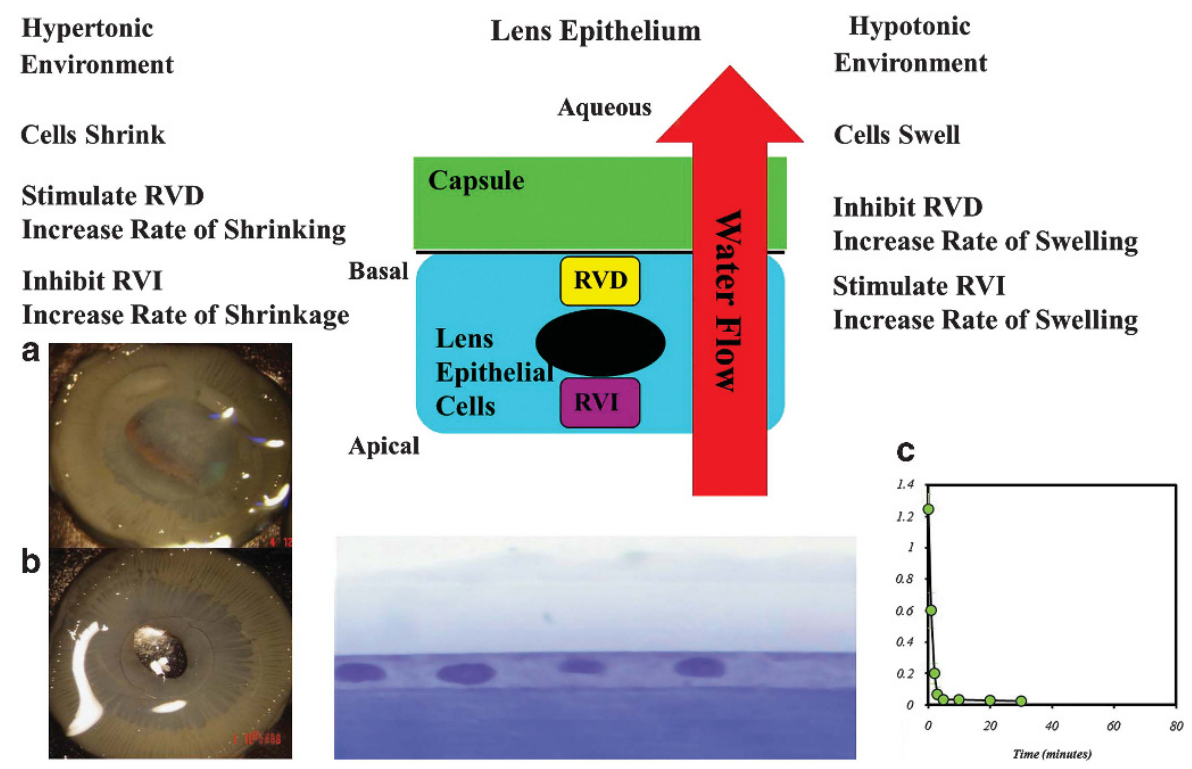

Figure 14 The proliferation of lens epithelial cells (PCO) subsequent to cataract extraction is of particular importance in paediatric cases. By differentially controlling the mechanisms responsible for modulating cell volume, such cells may be caused to swell and rupture, thereby preventing PCO. Work with JinJun Zhang has demonstrated the efficacy of this process in (a and b) showing the clarity of control and experimental animals 5 months after intraocular lens surgery. The mechanism to induce such cell death is rapid and will only put a few minutes on conventional cataract surgery (c). 
become apparent. All cells have a requirement to control the volume within certain limits. Cells do this by controlling their water content. In essence they have two systems of pumps whereby water is brought in or brought out of the cell. These can be considered as those concerned with regulatory volume increase (RVI), water in, and those concerned with regulatory volume decrease (RVD), water out (Figure 14). Our laboratory studies have now demonstrated that by upregulating water in (RVI) and simultaneously inhibiting water out (RVD) lens epithelial cells can be caused to swell until they burst. ${ }^{97}$ This mechanism results in a completely cell-free capsule. The dynamics of RVI and of RVD are specific to a given cell type and therefore the process may be undertaken without any collateral damage to other cell systems within the globe. This procedure should add no more than a few minutes to a conventional cataract extraction.

The four acellular membranes of the eye have been discussed with specific reference to changes in their management using lasers and I hope a better understanding of the implicit mechanisms has been related. Having worked diligently to present this lecture, I would like conclude with the second part of the quotation from Dickens, Sydney Carton on the steps to the guillotine 'It is a far, far better rest that I go to than I have ever known'.

\section{Conflict of interest}

The author declares no conflict of interest.

\section{Acknowledgements}

In putting together a manuscript of this kind summarising work that has taken place over almost 50 years, there are a huge number of individuals and institutions that have contributed and should be thanked. This work was financially supported by the following: Action Medical Research; Ann Allerton Fund; British Eye Research Foundation; British Retinitis Pigmentosa Society; Deutsche Forschungsgemeinschaft; Dr Hans and Mrs Gertrude Hirsch and Fight for Sight Small Grant Award; European Economic Community Concerted Action Biomedical and Health Research Programme; Fight For Sight; Frost Charitable Trust; Guide Dogs for the Blind Association; Iris Fund for Prevention of Blindness; JP Moulton Charity Trust; Lady Allerton Research Foundation; Macular Disease Society; Macula Society (USA); Medical Research Council; Ministry of Defence; National Eye Research Council; NIHR Moorfields Biomedical Research Centre; National Lottery Charities Board; Pocklington Foundation; PPP Healthcare Medical Trust; Research (Endowments) Committee, UMDS; Royal College of Surgeons
Ophthalmic Research Fund; Royal National Institute for the Blind; Royal Society; Sembal Trust; South Devon and Cornwall Institution for the Blind; Special Trustees of St Thomas' Hospital; United States Air Force; Wellcome Trust; Williams Fellowship for Medical and Scientific Research of the University of London; and Worshipful Company of Clothworkers. I thank the following commercial entities where collaborative or joint work was undertaken and funded: Alcon, Avedro, Diomed, Ellex, IntraLase, Keeler, Light Sciences Corporation, LensX, Pharmacia, Retica, Schwind, Summit Technology, and TEVA Pharmaceutical Industries Ltd. I am especially grateful to the Frost Trust who created my second chair in ophthalmology and have funded it for the past 23 years at both St Thomas's Hospital (King's College London) and the Institute of Ophthalmology (University College London). I would like to thank all my friends, colleagues, and students over the past 50 years for creating such a fantastic environment of intellectual challenge friendship. I would particularly like to thank the people who did all the work, my PhD and MD students whose efforts contributed to numerous papers, and many of whom are now professors with their own students in countries throughout the world. Finally, I would like to thank Ann Patmore for all her efforts, expertise, and particularly her patience for putting up with my obsessional attitudes in relation to papers and presentations.

\section{References}

1 Sanders MD. The Bowman Lecture Papilloedema: the pendulum of progress. Eye 1997; 11: 267-294.

2 James RR. British Masters of Ophthalmology Series 16 Sir William Bowman. Br J Opthalmol 1925; 9: 481-494.

3 Dickens C. In: Schlicke P (ed). The Oxford Companion to Charles Dickens: Anniversary Edition. Oxford University Press: Oxford, UK, 2011.

4 Mayhew H. London Labour and the London Poor: Volume I-IV. Griffin, Bohn and Co.: London, UK, 1861.

5 Jerrold B, Doré G. London: A Pilgrimage. Grant \& Co.: London, UK, 1872.

6 Woodham-Smith C. Florence Nightingale. Constable: London, UK, 1950.

7 Dickens C. Tale of Two Cities. Chapman \& Hall: London, UK, 1859.

8 Fisher R. The influence of age on some ocular basement membranes. Eye 1987; 1: 184-189.

9 Bowman W. Lectures on the Parts Concerned in the Operations on the Eye, and on the Structure of the Retina, Delivered at the Royal London Ophthalmic Hospital, Moorfields, June 1847. Longman, Brown, Green and Longmans: London, UK, 1849.

10 Duddell B. A Treatise of the Diseases of the Horny-Coat of the Eye, and the Various Kinds of Cataract. J Clark: London, UK, 1729.

11 Descemet J. An Sola Lens Crystallina Cataractae Sedes? Paris, 1758 
12 Demours P, Lettre de M, Demours àM. Petit,...: en réponse à sa critique d'un rapport sur une maladie de l'oeil survenue après l'inoculation de la petite vérole; contenant de nouvelles observations sur la structure de l'oeil, quelques remarques générales de pratique relatives aux maladies de cet organe 1767.

13 Daremberg Ch, Ruelle É. On the Naming of the Parts of Man P153 Paris from the Original Greek, Rufus (100AD) 1879.

14 Scheiner CSJ. Oculus hoc est: Fundamentum opticum [6], dealing with the physiological optics of the eye printed in Innsbruck by Daniel Bauer in 1619.

15 Zinn J. Descriptio Anatomica Oculi Humani Goettingen, Germany, 1755.

16 Boerhaave H. Dr Boerhaave's Academical Lectures on the Theory of Physic: Being a Genuine Translation of his Institutes and Explanatory Comment, Collated and Adjusted to Each Other, as they were Dictated to his Students at the University of Leyden. W Innys: London, UK, 1745.

17 Bruch CLW. Untersuchungen zur Kenntnis des kornigen Pigments der Wirbeltthiere Zurich, Switzerland, 1844.

18 Marshall J, Grindle CF. Fine structure of the cornea and its development. Trans Ophthalmol Soc UK 1978; 98(3): 320-328.

19 Marshall J, Hussain AA, Starita C, Moore DJ, Patmore AL. The retinal pigment epithelium. In: Marmor MF, Wolfensberger TJ (ed). The Retinal Pigment Epithelium. Oxford University Press: New York, NY, USA, 1998, pp 669-692.

20 Germundsson J, Karanis G, Fagerholm P, Lagali N. Age-related thinning of Bowman's layer in the human cornea in vivo. Invest Ophthalmol Vis Sci 2013; 54(9): 6143-6149.

21 Einstein A. Zur Quantentheorie der Strahlung (On the quantum mechanics of radiation). Phys Z 1917; 18: 121-128.

22 Gordon J, Zeiger $\mathrm{H}$, Townes $\mathrm{CH}$. The maser-new type of microwave amplifier, frequency standard, and spectrometer. Phys Rev 1955; 99: 1264.

23 Maiman TH. Nature 1960; 187: 493-494.

24 Zaret MM, Breinin GM, Schmidt H, Ripps H, Siegal IM, Solon LR. Ocular lesions produced by an optical maser (laser). Science 1961; 134: 1525-1526.

25 Marshall J, Mellerio J. Histology of the formation of retinal laser lesions. Exp Eye Res 1967; 6(1): 4-9.

26 Marshall J, Mellerio J. Pathological development of retinal laser photocoagulations. Exp Eye Res 1967; 6(4): 303-308.

27 Marshall J. Thermal and mechanical mechanisms in laser damage to the retina. Invest Ophthalmol 1970; 9(2): 97-115.

28 Marshall J, Mellerio J. Laser irradiation of retinal tissue. Br Med Bull 1970; 26(2): 156-160.

29 Smart D, Manson N, Marshall J, Mellerio J. New ocular hazard of mode locking in CW lasers. Nature 1970; 227(5263): 1149-1150.

30 Marshall J, Mellerio J. Disappearance of retino-epithelial scar tissue from ruby laser photocoagulations. Exp Eye Res 1970; 12(2): 173-174.

31 Environmental Heath Criteria 23. Lasers and Optical Radiation. World Health Organisation: Geneva, Switzerland, 1982.

32 Blinding Laser Weapons. In: Doswald-Beck L (ed). Reports of the Meetings of Experts Convened by the International Committee of the Red Cross on Battlefield Laser Weapons 1989-91 Geneva, 1993.

33 Marshall J, Hamilton AM, Bird AC. Intra-retinal absorption of argon laser irradiation in human and monkey retinae. Experientia 1974; 30(11): 1335-1337.
34 Marshall J, Hamilton AM, Bird AC. Histopathology of ruby and argon laser lesions in monkey and human retina. A comparative study. Br J Ophthalmol 1975; 59(11): 610-630.

35 Marshall J. Lasers in ophthalmology: the basic principles. Eye (Lond) 1998; 2(Suppl): S98-S112.

36 McHugh JD, Marshall J, Ffytche TJ, Hamilton AM, Raven A, Keeler CR. Initial clinical experience using a diode laser in the treatment of retinal vascular disease. Eye (Lond) 1989; 3(Part 5): 516-527.

37 Watts GK. Ruby laser damage and pigmentation of the iris. Exp Eye Res 1969; 8(4): 470-476.

38 McHugh JDA, Marshall J, Capon M, Rothery S, Raven A, Naylor RP. Transpupillary retinal photocoagulation in the eyes of rabbit and human using a diode laser. Lasers Light Ophthalmol 1998; 2(2): 125-143.

39 Marshall J, Raven A, Welford W, Ness K. Surface erosion using lasers. US Patent No. 4941 093, 1990 (filed in 1986).

40 Trokel SL, Srinivasan R, Braren B. Excimer laser surgery of the cornea. Am J Ophthalmol 1983; 96(6): 710-715.

41 Marshall J, Trokel S, Rothery S, Schubert H. An ultrastructural study of corneal incisions induced by an Excimer laser at $193 \mathrm{~nm}$. Ophthalmology 1985; 92(6): 749-758.

42 Marshall J, Trokel S, Rothery S, Krueger RR. A comparative study of corneal incisions induced by diamond and steel knives and two ultraviolet radiations from an excimer laser. Br J Ophthalmol 1986; 70(7): 482-501.

43 Marshall J, Trokel S, Rothery S, Krueger RR. Photoablative reprofiling of the cornea using an excimer laser: photorefractive keratectomy. Lasers Ophthalmol 1986; 1: 21-48.

44 Munnerlyn CR, Koons SJ, Marshall J. Photorefractive keratectomy: a technique for laser refractive surgery. J Cataract Refract Surg 1988; 14(1): 46-52.

45 O'Brart DP, Gartry DS, Lohmann CP, Muir MGK, Marshall J. Excimer laser photorefractive keratectomy for myopia: comparison of 4.00- and 5.00-millimeter ablation zones. J Refract Corneal Surg 1994; 10(2): 87-94.

46 O'Brart DPS, Corbett MC, Verma S, Heacock G, Lohmann CP, Muir MGK et al. Effects of ablation diameter, depth, and edge contour on the outcome of Excimer laser photorefractive keratectomy (abstract). J Refract Surgery 1995; 11: S285.

47 Corbett MC, Marshall J. Corneal haze after photorefractive keratectomy. A review of etiological mechanisms and treatment options. Lasers Light Ophthalmol 1996; 7(4): 173-196.

48 O'Brart DP, Lohmann CP, Klonos G, Corbett MC, Pollock WS, Kerr-Muir MG et al. The effects of topical corticosteroids and plasmin inhibitors on refractive outcome, haze, and visual performance after photorefractive keratectomy. A prospective, randomized, observermasked study. Ophthalmology 1994; 101(9): 1565-1574.

49 Verma S, Corbett MC, Marshall J. A prospective randomized, double-masked trial to evaluate the role of topical anesthetics in controlling pain after photorefractive keratectomy. Ophthalmology 1995; 102(12): 1918-1924.

50 Buratto L, Ferrari M, Rama P. Excimer laser intrastromal keratomileusis. Am J Ophthalmol 1992; 113(3): 291-295.

51 Pallikaris IG, Papatzanaki ME, Siganos DS, Tsilimbaris MK. A corneal flap technique for laser in situ keratomileusis. Human studies. Arch Ophthalmol 1991; 109(12): 1699-1702.

52 Shortt AJ, Allan BD, Evans JR. Laser-assisted in situ keratomileusis (LASIK) versus photorefractive keratectomy (PRK) for myopia. Cochrane Database Syst Rev 2013; 1: CD005135 (review). 
53 Petzing JN, Tyrer JR. Recent developments and applications in electronic speckle pattern interferometry. J Strain Anal Eng Des 1998; 33(2): 153-169.

54 Sheikh Ibrahim J, Petzing JN, Tyrer JR. Deformation analysis of aircraft wheels using speckle shearing interferometry. Proc Inst Mech Eng Part G 2004; 218: 287-295.

55 Knox Cartwright NE, Tyrer JR, Marshall J. Age-related differences in the elasticity of the human cornea. Invest Ophthalmol Vis Sci 2011; 52(7): 4324-4329.

56 Abahussin M, Hayes S, Knox Cartwright NE, Kamma-Lorger CS, Khan Y, Marshall J et al. 3D collagen orientation study of the human cornea using X-ray diffraction and femtosecond laser technology. Invest Ophthalmol Vis Sci 2009; 50(11): 5159-5164.

57 Jaycock PD, Lobo L, Ibrahim J, Tyrer J, Marshall J. Interferometric technique to measure biomechanical changes in the cornea induced by refractive surgery. $J$ Cataract Refract Surg 2005; 31(1): 175-184.

58 Knox Cartwright NE, Tyrer JR, Jaycock PD, Marshall J. Effects of variation in depth and side cut angulations in LASIK and thin-flap LASIK using a femtosecond laser: a biomechanical study. J Refract Surg 2012; 28(6): 419-425.

59 Durrie DS, Slade SG, Marshall J. Wavefront-guided Excimer laser ablation using photorefractive keratectomy and sub-Bowman's keratomileusis: a contralateral eye study. J Refract Surg 2008; 24(1): S77-S84.

60 Reinstein DZ, Archer TJ, Gobbe M. Accuracy and reproducibility of cap thickness in small incision lenticule extraction. J Refract Surg 2013; 29(12): 810-815.

61 Koller T, Seiler T. Therapeutic cross-linking of the cornea using riboflavin/UVA. Klin Monbl Augenheilkd 2007; 224(9): 700-706; (review; in German).

62 Knox Cartwright NE, Tyrer JR, Marshall J. In vitro quantification of the stiffening effect of corneal cross-linking in the human cornea using radial shearing speckle pattern interferometry. J Refract Surg 2012; 28(7): 503-508.

63 Tomita M, Yoshida Y, Yamamoto Y, Mita M, Waring IV, G. In vivo confocal laser microscopy of morphologic changes after simultaneous LASIK and accelerated collagen crosslinking for myopia: one-year results. J Cataract Refract Surg 2014; 40(6): 981-990.

64 Seven I, Dupps WJ. Patient-Specific finite element simulations of standard incisional astigmatism surgery and a novel patterned collagen crosslinking approach to astigmatism treatment. J Med Dev 2013; 7(4): 0409131-0409132.

65 Kanellopoulos AJ, Pamel GJ. Review of current indications for combined very high fluence collagen cross-linking and laser in situ keratomileusis surgery. Indian J Ophthalmol 2013 61(8): 430-432; (review).

66 Marshall J, Hersh P, Muller D. Corneal Collagen CrossLinking. eBook Avedro Inc: Waltham, MA, USA, 2013.

67 Ugarte M, Hussain AA, Marshall J. An experimental study of the elastic properties of the human Bruch's membranechoroid complex: relevance to ageing. Br J Ophthalmol 2006; 90(5): 621-626.

68 Young RW. The Bowman Lecture, 1982. Biological renewal. Applications to the eye. Trans Ophthalmol Soc UK 1982; 102(Part 1): 42-75.

69 Bindewald A, Bird AC, Dandekar SS, Dolar-Szczasny J, Dreyhaupt J, Fitzke FW et al. Classification of fundus autofluorescence patterns in early age-related macular disease. Invest Ophthalmol Vis Sci 2005; 46(9): 3309-3314.
70 Grindle CF, Marshall J. Ageing changes in Bruch's membrane and their functional implications. Trans Ophthalmol Soc UK 1978; 98(1): 172-175.

71 Bird AC, Marshall J. Retinal pigment epithelial detachments in the elderly. Trans Ophthalmol Soc UK 1986; 105(Part 6): 674-682; (review).

72 Moore DJ, Hussain A A, Marshall J. Age-related variation in the hydraulic conductivity of Bruch's membrane. Invest Ophthalmol Vis Sci 1995; 36(7): 1290-1297.

73 Starita C, Hussain AA, Pagliarini S, Marshall J. Hydrodynamics of ageing Bruch's membrane: implications for macular disease. Exp Eye Res 1996; 62(5): 565-572.

74 Hussain AA, Rowe L, Marshall J. Age-related alterations in the diffusional transport of amino acids across the human Bruch's-choroid complex. J Opt Soc Am A 2002; 19(1): 166-172.

75 Guo L, Hussain AA, Limb GA, Marshall J. Age-dependent variation in metalloproteinase activity of isolated human Bruch's membrane and choroid. Invest Ophthalmol Vis Sci 1999; 40(11): 2676-2682.

76 Weber BHF, Vogt G, Pruett RC, Stöhr H, Felbor U. Mutations in the tissue inhibitor of metalloproteinases-3 (TIMP3) in patients with Sorsby's fundus dystrophy. Nat Genet 1994; 8: 352-356.

77 Capon MR, Marshall J, Krafft JI, Alexander RA, Hiscott PS, Bird AC. Sorsby's fundus dystrophy. A light and electron microscopic study. Ophthalmology 1989; 96(12): 1769-1777.

78 Kumar A, El-Osta A, Hussain AA, Marshall J. Increased sequestration of matrix metalloproteinases in ageing human Bruch's membrane: implications for ECM turnover. Invest Ophthalmol Vis Sci 2010; 51(5): 266470.

79 Hussain AA, Lee Y, Marshall J. High molecular-weight gelatinase species of human Bruch's membrane: compositional analyses and age-related changes. Invest Ophthalmol Vis Sci 2010; 51(5): 2363-2371.

80 Hussain AA, Lee Y, Zhang JJ, Marshall J. Disturbed matrix metalloproteinase activity of Bruch's membrane in agerelated macular degeneration. Invest Ophthalmol Vis Sci 2011; 52(7): 4459-4466.

81 Chew EY, Klein ML, Clemons TE, Agrón E, Ratnapriya R, Edwards $\mathrm{AO}$ et al. No clinically significant association between CFH and ARMS2 genotypes and response to nutritional supplements: AREDS Report Number 38. Ophthalmology 2014; e-pub ahead of print 24 June 2014; doi:10.1016/j.ophtha.2014.05.008.

82 Marshall J, Bird AC. Retinal receptor disorders without known metabolic abnormalities. In Garner A, Klintworth GK (eds). Pathobiology of Ocular Disease. Marcel Dekker: New York, NY, USA, 1982, pp 1167-1220.

83 Sundaram V, Moore AT, Ali RR, Bainbridge JW. Retinal dystrophies and gene therapy. Eur J Pediatr 2012; 171(5): 757-765.

84 Pearson RA, Hippert C, Graca AB, Barber AC. Photoreceptor replacement therapy: challenges presented by the diseased recipient retinal environment. Vis Neurosci 2014; 19: 1-12.

85 Sarks SH. Ageing and degeneration in the macular region: a clinico-pathological study. Br J Ophthalmol 1976; 60(5): 324-341.

86 Ahir A, Guo L, Hussain AA, Marshall J. Expression of metalloproteinases from human retinal pigment epithelial cells and their effects on the hydraulic conductivity of Bruch's membrane. Invest Ophthalmol Vis Sci 2001; 43(2): 458-465. 
87 Zhang JJ, Sun Y, Hussain AA, Marshall J. Laser-mediated activation of human retinal pigment epithelial cells and concomitant release of matrix metalloproteinases. Invest Ophthalmol Vis Sci 2012; 53(6): 2928-2937.

88 Roider J, Brinkmann R, Wirbelauer C, Laqua H, Birngruber R. Retinal sparing by selective retinal pigment epithelial photocoagulation. Arch Ophthalmol 1999; 117(8): 1028-1034.

89 Plunkett M, Hussain A, Marshall J. Retinal Regeneration. US Patent No. 8562595 (WO2008049164), 2010 (filed in 2007).

90 Marshall J, Clover G, Rothery S. Some new findings on retinal irradiation by krypton and argon lasers. In Birngruber R, Gabel V-P (eds). Laser Treatment and Photocoagulation of the Eye. Springer: Berlin, Germany, 1984, pp 21-37.

91 Pelosini L, Hamilton R, Mohamed M, Hamilton AM, Marshall J. Retina rejuvenation therapy for diabetic macular edema: a pilot study. Retina 2013; 33(3): 548-558.

92 Guymer RH, Brassington KH, Dimitrov P, Makeyeva G, Plunkett M, Xia W et al. Nanosecond-laser application in intermediate AMD: 12-month results of fundus appearance and macular function. Clin Exp Ophthalmol 2014; 42(5): 466-479.

93 Naumann GO. The Bowman Lecture. Eye (Lond) 1995; 9(Part 4): 395-421; (review).

94 Gorovoy MS. Descemet-stripping automated endothelial keratoplasty. Cornea 2006; 25: 886-889.

95 Fankhauser F, Kwasniewska S. Clinical effects of the $\mathrm{Nd}$ :YAG laser operating in the photodisruptive and thermal modes: a review. Ophthalmologica 2003; 217(1): 1-16; (review).

96 Shah A, Spalton DJ, Gilbert C, Vasavada A, Boyce JF, Minassian D et al. Effect of intraocular lens edge profile on posterior capsule opacification after extracapsular cataract surgery in a developing country. J Cataract Refract Surg 2007; 33(7): 1259-1266.

97 Zhang JJ. Treatment solution and method for preventing posterior capsule opacification by selectively inducing detachment and death of lens epithelial cells. Patent No. 2499195 (WO/2004/026288), 2004 (filed 28 August 2003). 